\title{
Re-drawing the Maps for Endemic Mycoses
}

\author{
Nida Ashraf • Ryan C. Kubat • Victoria Poplin • Antoine A. Adenis • \\ David W. Denning • Laura Wright • Orion McCotter • Ilan S. Schwartz • \\ Brendan R. Jackson • Tom Chiller • Nathan C. Bahr
}

Received: 31 August 2019/Accepted: 24 January 2020/Published online: 10 February 2020

(C) The Author(s) 2020

\begin{abstract}
Endemic mycoses such as histoplasmosis, coccidioidomycosis, blastomycosis, paracoccidioidomycosis, and talaromycosis are well-known causes of focal and systemic disease within specific geographic areas of known endemicity. However, over the past few decades, there have been increasingly
\end{abstract}

Handling Editor: Ferry Hagen.

Disclaimer: The findings and conclusions in this report are those of the authors and do not necessarily represent the official position of the Centers for Disease Control and Prevention.

Nida Ashraf and Ryan C. Kubat have contributed equally to this manuscript.

N. Ashraf · R. C. Kubat · N. C. Bahr $(\varangle)$

Division of Infectious Diseases, Department of Internal Medicine, University of Kansas, Kansas City, KS, USA e-mail: nbahr@kumc.edu

V. Poplin

Department of Internal Medicine, University of Kansas, Kansas City, KS, USA

A. A. Adenis

Centre d'Investigation Clinique Antilles-Guyane, Inserm 1424, Centre Hospitalier de Cayenne, Cayenne, French Guiana

D. W. Denning

Faculty of Biology, Medicine, and Health, University of Manchester, Manchester Academic Health Science

Centre, Manchester, UK frequent reports of infections due to endemic fungi in areas previously thought to be "non-endemic." There are numerous potential reasons for this shift such as increased use of immune suppressive medications, improved diagnostic tests, increased disease recognition, and global factors such as migration, increased travel, and climate change. Regardless of the causes, it has become evident that our previous understanding of endemic regions for these fungal diseases needs to evolve. The epidemiology of the newly described Emergomyces is incomplete; our understanding of it continues to evolve. This review will focus on the evidence underlying the established areas of endemicity for these mycoses as well as new data and reports from medical literature that support the re-thinking

\author{
L. Wright \\ Geographic Research Analysis and Services Program, \\ Division of Toxicology and Human Health Services, \\ Centers for Disease Control and Prevention, Atlanta, GA, \\ USA \\ O. McCotter · B. R. Jackson - T. Chiller \\ Mycotic Branch, Centers for Disease Control and \\ Prevention, Atlanta, GA, USA
}

\section{S. Schwartz}

Division of Infectious Diseases, Department of Medicine, Faculty of Medicine \& Dentistry, University of Alberta, Edmonton, AB, Canada 
these geographic boundaries. Updating the endemic fungi maps would inform clinical practice and global surveillance of these diseases.

Keywords Histoplasmosis - Coccidioidomycosis · Blastomycosis · Paracoccidioidomycosis . Talaromycosis $\cdot$ Emergomyces $\cdot$ Endemic fungi

\section{Introduction}

Histoplasmosis, coccidioidomycosis, blastomycosis, paracoccidioidomycosis, talaromycosis, and emergomycosis are termed endemic mycoses because of their historically regular occurrence in limited geographic ranges, and are recognized as substantial causes of morbidity and mortality particularly in the setting of HIV/AIDS, other immunosuppressive medical conditions, or the use of immunosuppressive medications [1-3]. Due to lack of adequate surveillance data worldwide, especially in low-resource settings, it is difficult to estimate the true burden and geographic distribution of these conditions [2]. Further, in some cases, the best diagnostic tests are not widely available outside of the USA (e.g., Histoplasma antigen testing), meaning diagnosis requires a high index of suspicion [3, 4]. In recent years, increased attention has been paid to endemic mycoses diagnosed outside of their established geographic ranges, including many with no known exposure to endemic regions. Thus, re-thinking our understanding of the established geographic distribution of these infections is warranted [5-14]. In this review, we will examine the evolving geographic landscape of endemic mycoses worldwide and further underscore the need for improved surveillance, availability of diagnostic tests, and disease awareness among healthcare providers about the wider than previously thought distributions of these diseases.

\section{Methods}

We reviewed the literature on PubMed using search terms "histoplasmosis," "coccidioidomycosis," "blastomycosis," "talaromycosis," "penicilliosis," and "emergomycosis" with the intent of detecting the widest geographic scope of these diseases as possible, although this was not designed to be a systematic review. We searched for case reports, cohort studies, and studies of skin testing, seropositivity, environmental surveys and outbreaks. Where numerous case reports exist, earlier case reports were excluded for purposes of brevity, assuming their inclusion would not add to the overall message (e.g., for a given disease, we included two of 33 case reports from one country). Figure 1 refers to hyperendemic areas of histoplasmosis - these are areas with known high rates of infection and/or skin histoplasmin positivity or seroprevalence. Other categories in this figure are based on frequency of case reports and background prevalence in the context of expert opinion. Only cases without travel to previously known endemic areas were included. For traditionally non-endemic areas where only rare cases have been reported without culture or molecular confirmation, results should be interpreted with caution.

\section{Histoplasmosis}

Histoplasmosis in humans is acquired primarily by inhalation of spores of Histoplasma capsulatum var. capsulatum or Histoplasma capsulatum var. duboisii [15]. There is an additional variety, H. capsulatum var. farciminosum, which has predominantly been described as an equine pathogen but, based on molecular analyses, may have a broader host range which could include humans [16, 17]. Histoplasmosis was first described by Samuel Darling in a worker during construction of the Panama Canal in 1906 [18]. As histoplasmosis was further characterized, it was understood to be intensely endemic in the Ohio and Mississippi River Valleys in the USA as well as in Central and South America [19, 20]. More recently, analysis of phylogenetics and phenotypic characteristics of Histoplasma isolates show distinct differences between isolates from different regions suggesting they may actually represent distinct Histoplasma species [21]. Within the traditional endemic areas, Histoplasma is often found concentrated in areas of "microfoci" which are characteristically areas of soil contaminated with bird or bat guano such as caves, tunnels, chicken coops, or areas of excavated soil [19]. In recent decades, the HIV/AIDS pandemic and the increased use of immunosuppressive agents have led to cases of histoplasmosis reported from previously "non-endemic areas" and have revealed the truly 


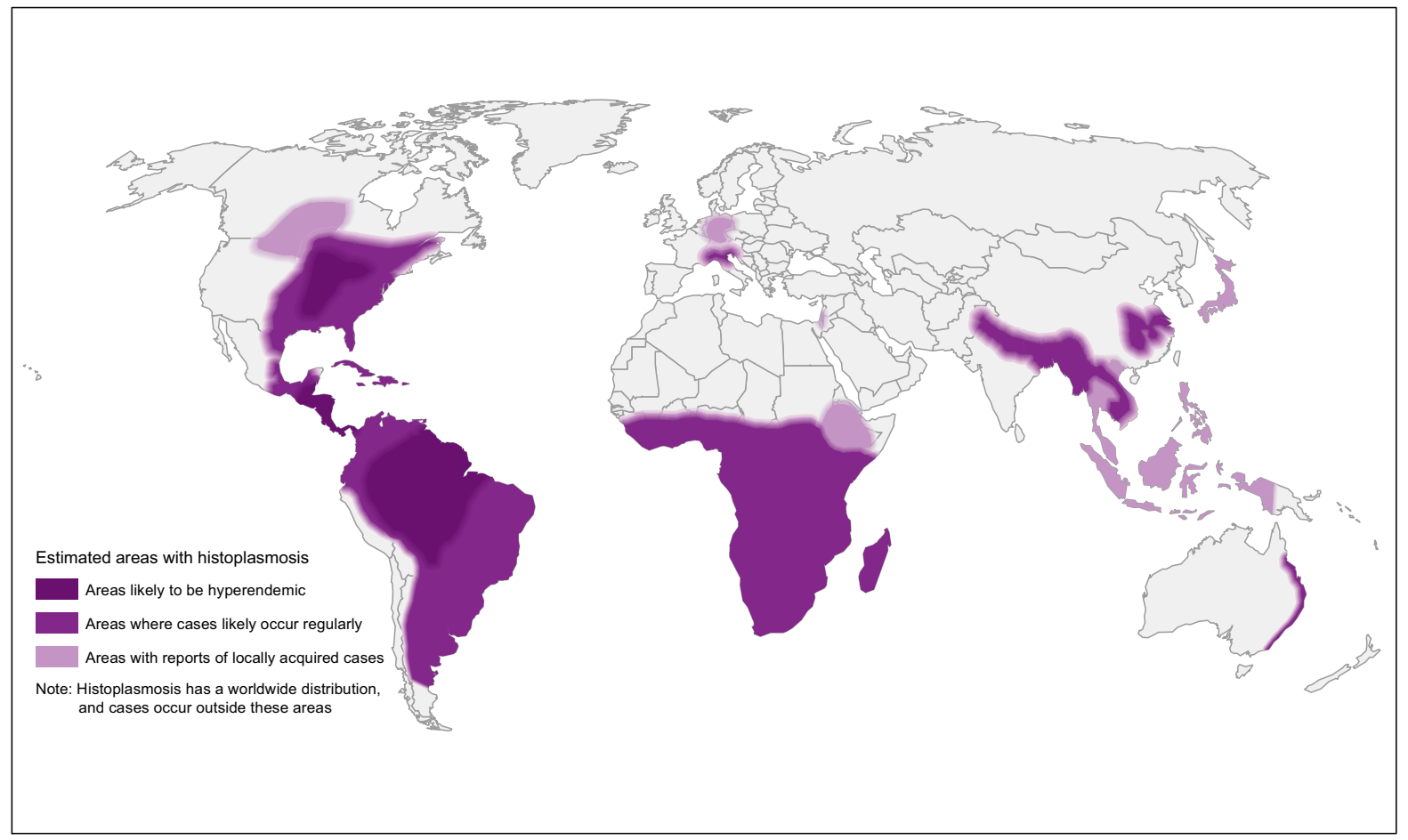

Fig. 1 World map estimating regions most likely to have histoplasmosis based on literature review

global distribution of histoplasmosis [12, 19] (Table 1).

Within the USA, while the Mississippi and Ohio River Valley regions are highly endemic, histoplasmosis occurs well-beyond these boundaries. In a study of histoplasmosis cases among the US Medicare beneficiaries, nearly $12 \%$ of cases were from nonendemic areas [14]. A study of histoplasmosis diagnoses among privately insured patients showed that $20 \%$ of cases occurred outside traditionally defined endemic regions [5]. While these larger studies were unable to evaluate cases on an individual basis for travel to endemic areas, other publications report several human cases of autochthonous histoplasmosis from areas not previously thought to be endemic. These include California, Arizona, Idaho, Montana, and New York as well as states north of the classical endemic area such as Minnesota, Wisconsin, and Michigan [6, 22-25]. Moreover, veterinary cases have been reported to extend into southwest states such as New Mexico and Colorado and as far north as Alaska [26, 27]. In Canada, histoplasmosis is endemic in Quebec and Ontario along the St. Lawrence Seaway and the Great Lakes Drainage Basin [7, 28, 29]. More recently, several laboratory confirmed cases with local acquisition have been reported in Alberta, and there has been at least one confirmed common source outbreak in Saskatchewan (IS Schwartz, unpublished data) [30, 31].

Histoplasmosis is endemic throughout much of Central and South America with an estimated 32\% histoplasmin skin test positivity throughout Latin America (with regional variability) [32]. Chile has an estimated prevalence of $0.1 \%$ and, in a 2017 case series, all nine cases occurred in the setting of foreign travel or immigration [32, 33]. In Argentina, 30-40\% of the population has been estimated to have had exposure to histoplasmosis [34]. In Mexico, an estimated 112-325 cases of acute pulmonary or disseminated histoplasmosis have been reported annually, primarily in the central and southeastern states of Veracruz, Oaxaca, Campeche, Tabasco, and Chiapas, although this is considered a significant underestimation due to variable diagnostic methodologies, lack of surveillance programs, and lack of diagnostic capabilities in many areas [34, 35]. In Central America, reported histoplasmin skin test positivity ranges from $37 \%$ in Costa Rica and Nicaragua to $57 \%$ in Guatemala [32]. 
Table 1 Selected areas of Histoplasma endemicity outside the North America based on the histoplasmin skin reactivity

\begin{tabular}{|c|c|c|}
\hline Country, year, region & Number tested (population) & $\begin{array}{l}\text { Histoplasmin skin test positivity (\%), } \\
\text { (location if multiple in study) }\end{array}$ \\
\hline \multicolumn{3}{|l|}{ Africa } \\
\hline Mali, 1969 [304] & 1253 (school children) & 6.0 \\
\hline Nigeria, 2018 [50] & 735 (HIV-infected patients) & $\begin{array}{l}0 \text { (Lagos), } 3 \text { (Yola), } 2 \text { (Ilorin), } 6 \text { (Calabar), } \\
3 \text { (Ibadan), } 15 \text { (Benin) }\end{array}$ \\
\hline $\begin{array}{l}\text { Nigeria, Anambra State, } \\
1996[51]\end{array}$ & $\begin{array}{l}40 \text { (cave guides, traders, farmers near a cave), } 620 \\
\text { (traders, farmers, palm oil workers) }\end{array}$ & $\begin{array}{l}35.0 \\
8.8\end{array}$ \\
\hline Nigeria, 1991 [305] & $\begin{array}{l}1087 \text { (healthy subjects), } 226 \text { (pulmonary hospital } \\
\text { patients) }\end{array}$ & $\begin{array}{l}1.7-5.0(H c c), 0.5-4.5(H c d) \\
8.9(H c c), 6.6(H c d)\end{array}$ \\
\hline $\begin{array}{l}\text { Somalia, Mogadishu and } \\
\text { Jilib, } 1979 \text { [52] }\end{array}$ & 1014 (NA) & 0.3 \\
\hline Uganda, 1970 [53] & 1114 (residents) & 3.9 \\
\hline \multicolumn{3}{|l|}{ Asia } \\
\hline Bangladesh, 1971 [67] & 2572 (pulmonary disease patients) & 17.9 \\
\hline China, $2001[68]$ & 735 (hospitalized patients and healthy residents) & 8.9 (Hunan), 15.1 (Jiangsu), 2.1 (Xinjiang) \\
\hline $\begin{array}{l}\text { China, Sichuan Province, } \\
1996 \text { [306] }\end{array}$ & $\begin{array}{l}271 \text { (healthy students and workers) } \\
28 \text { (hospitalized TB patients) }\end{array}$ & $\begin{array}{l}21.8 \\
28.6\end{array}$ \\
\hline India, $1955[61]$ & 962 (NA) & 1.9 \\
\hline India, Delhi, 1962 [61] & 8062 (NA) & 6.8 \\
\hline $\begin{array}{l}\text { India, Kolkata (Calcutta), } \\
1956[61]\end{array}$ & 4855 (NA) & 0.7 \\
\hline Indonesia, 1956 [75] & 2542 (students, hospital patients, nurses) & 2.7 (children), 9-12 (adults), Jakarta \\
\hline Indonesia, 1956 [307] & $\begin{array}{l}281 \text { in Surabaya, } 340 \text { in Kedisan (school children/ } \\
\text { villagers) }\end{array}$ & 32 (Surabaya), 63.6 (Kedisan) \\
\hline $\begin{array}{l}\text { Indonesia, Medan, } 1997 \\
\text { [308] }\end{array}$ & 1265 medical students & 13.6 \\
\hline $\begin{array}{l}\text { Malaysia, Sarawak, } 1963 \\
\text { [309] }\end{array}$ & 181 school children/hospitalized patients & 0.5 \\
\hline $\begin{array}{l}\text { Malaysia, Kuala Lumpur, } \\
1964 \text { [310] }\end{array}$ & 224 adults & 10.5 \\
\hline $\begin{array}{l}\text { Malaysia, Sabah, } 1971 \\
\text { [76] }\end{array}$ & 3824 (residents) & 11.8 \\
\hline \multirow[t]{2}{*}{ Myanmar, 1952 [96] } & 3558 (prisoners) & $\begin{array}{l}\text { 14.5-27.1 (Lower and Rangoon), 4.0-8.4 } \\
\text { (Upper) }\end{array}$ \\
\hline & & 86.4 (Maguee) \\
\hline $\begin{array}{l}\text { Philippines, Luzon Island, } \\
\text { 2001, } 1964 \text { [74] }\end{array}$ & 143 (electric company employees) & 25.9 \\
\hline $\begin{array}{l}\text { Philippines, Manilla, } 1964 \\
\text { [311] }\end{array}$ & 2577 (naval recruits) & 6.4 \\
\hline $\begin{array}{l}\text { Thailand, 1966-1968, } \\
\text { [312] }\end{array}$ & NA (NA) & $\begin{array}{l}\text { 3-9 (central), 7-14 (northern), 15-36 } \\
\text { (southeast and southern) }\end{array}$ \\
\hline $\begin{array}{l}\text { Thailand, Bangkok, } 1967 \\
\text { [313] }\end{array}$ & 497 (medical/nursing students) & 5.6 \\
\hline Thailand, 1968 [73] & 4211 (prisoners) & 14 (northern), 9 (central), 36 (southern) \\
\hline $\begin{array}{l}\text { Vietnam, 1956, Saigon } \\
\text { [307] }\end{array}$ & 303 school children/villagers & 33.7 \\
\hline \multicolumn{3}{|l|}{ Caribbean } \\
\hline Barbados, 1981 [314] & 103 (NA) & 4 \\
\hline
\end{tabular}


Table 1 continued

\begin{tabular}{|c|c|c|}
\hline Country, year, region & Number tested (population) & $\begin{array}{l}\text { Histoplasmin skin test positivity }(\%) \text {, } \\
\text { (location if multiple in study) }\end{array}$ \\
\hline Trinidad, 1981 [314] & 86 (NA) & 42 \\
\hline \multicolumn{3}{|l|}{ Central and South America } \\
\hline $\begin{array}{l}\text { Argentina, San Martin } \\
\text { City, } 1996[315]\end{array}$ & 315 (children) & 9.2 \\
\hline Belize, 1978 [316] & 141 (NA) & 40 \\
\hline $\begin{array}{l}\text { Brazil, Amazon, } 1994 \\
\text { [317] }\end{array}$ & NA (Tupi-Monde Amerindian populations) & 78.7 (Surui), 5.8 (Gaviao), 80.5 (Zoro) \\
\hline Brazil, Recife, 1966 [318] & 1006 (hospital patients) & 20.5 \\
\hline Brazil, Belem, 1966 [318] & 258 (hospital patients and medical students) & 43.4 \\
\hline $\begin{array}{l}\text { Brazil, Minas Gerais State, } \\
1996 \text { [319] }\end{array}$ & 417 (miners) & 17.5 \\
\hline Colombia, $1968[320]$ & NA (NA) & 21.0 \\
\hline Guatemala, 1960 [321] & 821 (hospital patients) & $23-81$ \\
\hline $\begin{array}{l}\text { Mexico, Guerrero State, } \\
1997 \text { [322] }\end{array}$ & 139 (cave guides, guano collectors, fishermen) & $\begin{array}{l}87.3 \text { (Jutlahuaca), } 76.9 \text { (Olinala), } 3.8 \\
\text { (Coyuca) }\end{array}$ \\
\hline $\begin{array}{l}\text { Venezuela, Bolivar State, } \\
2004 \text { [323] }\end{array}$ & 157 (residents, farmers) & 42.7 \\
\hline \multicolumn{3}{|l|}{ Europe } \\
\hline $\begin{array}{l}\text { Italy, Po Valley, } 1994 \\
\text { [109] }\end{array}$ & 776 (students) & 1.2 \\
\hline
\end{tabular}

Hcc-Histoplasma capsulatum var. capsulatum; Hcd-Histoplasma capsulatum var. duboisii; NA—information not available

In South America, disseminated histoplasmosis is increasingly identified in persons with new HIV diagnoses and is estimated to be as common in this setting as tuberculosis [32, 36-39]. Further, the true incidence of histoplasmosis in HIV/AIDS is likely substantially higher than currently recognized due to limited availability of Histoplasma antigen testing. In Brazil, the introduction of such testing led to a 53.8\% increase in diagnostic yield [40]. Scattered cases of histoplasmosis have been identified throughout the Caribbean islands including outbreaks in the Dominican Republic and Cuba with endemicity recognized in Jamaica [41-44]. Histoplasmin skin test positivity rates as high as $42 \%$ in Trinidad and Tobago suggest that Caribbean cases may be under-recognized as well [45].

Histoplasmosis in Africa is caused by both $H$. capsulatum var. capsulatum, which is found throughout much of Africa, and $H$. capsulatum var. duboisii, which has been reported throughout West Africa (with the majority of cases from Nigeria), the Democratic Republic of the Congo, Uganda, Tanzania, and scattered throughout central and eastern Africa including isolated cases from Madagascar [46-48]. In contrast to $H$. capsulatum var. capsulatum, $H$. capsulatum var. duboisii predominantly causes skin and soft tissue infections and rarely involves the lungs [46, 49]. A literature review of all published cases of histoplasmosis from Africa found a total of 470 cases from 1972-2017, with the highest number of cases originating from West Africa [46]. The majority of West African cases are reported from Nigeria, where studies evaluating histoplasmin skin sensitivity have shown rates ranging from $4.4 \%$ in a predominantly urban population up to $35 \%$ near a bat cave in a rural part of the country [46, 50, 51]. Additional studies of histoplasmin sensitivity in Uganda showed a positivity rate ranging from $0.4 \%-10 \%$ in separate Ugandan districts, while a study in Somalia found a total positivity rate of only $0.3 \%[52,53]$. More recently, 
Table 2 States in which selected endemic mycoses are notifiable as of February 2019

Content source: Centers for Disease Control and Prevention, National Center for Emerging and Zoonotic Infectious Diseases (NCEZID), Division of Foodborne, Waterborne, and Environmental Diseases (DFWED)

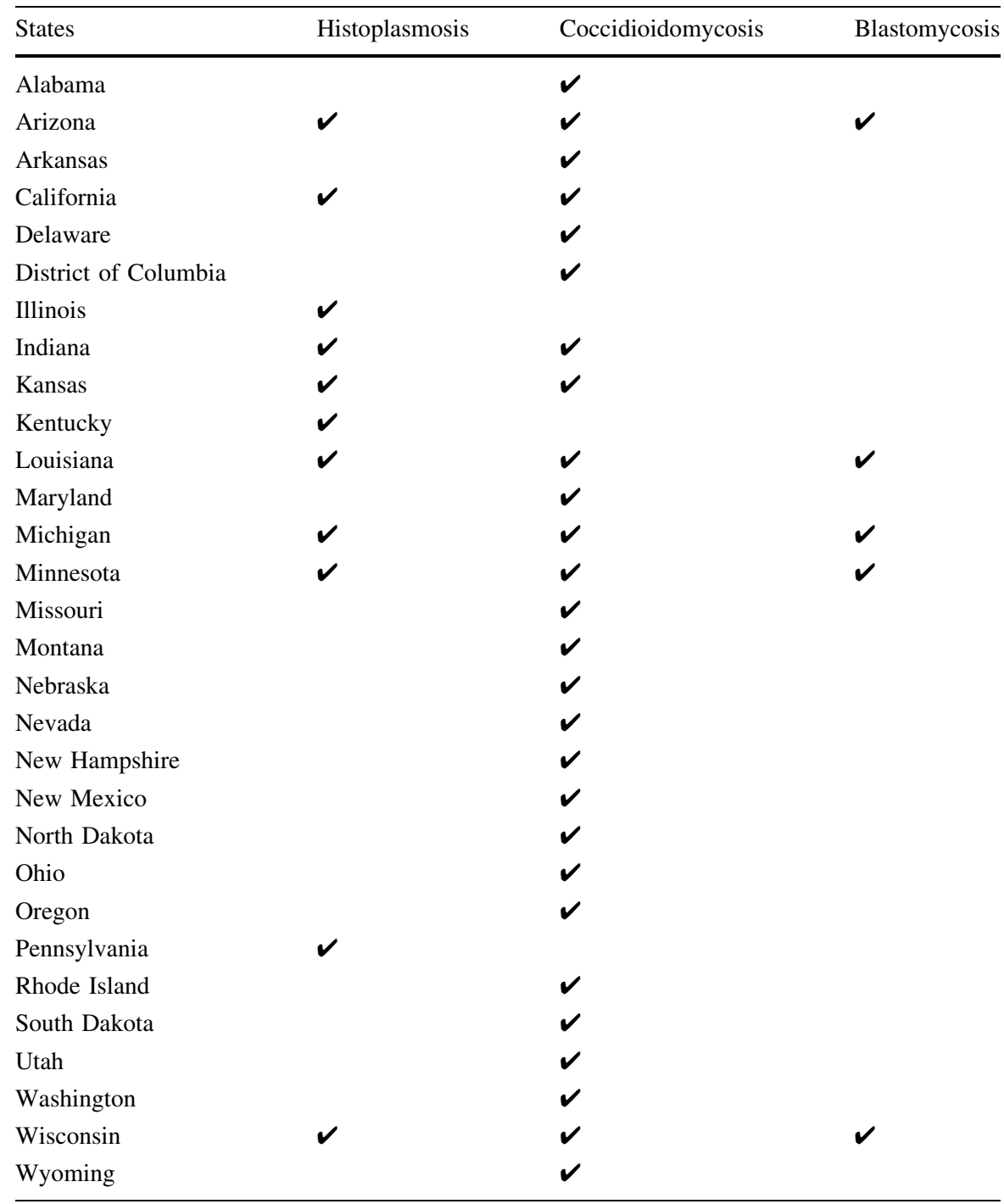

Histoplasma antigen and anti-Histoplasma antibody studies have been performed, with zero of 100 Somali refugees residing in Kenya exhibiting seropositivity for anti-Histoplasma IgG and $1.3 \%$ of Ugandan persons living with HIV/AIDS exhibiting anti-Histoplasma $\operatorname{IgG}$ seropositivity (with no positive antiHistoplasma IgM or Histoplasma serum, urine, or cerebrospinal fluid antigens among 151 subjects) $[54,55]$. One striking study from Maputo, Mozambique, found that $58 \%$ of $\mathrm{HIV}$-infected patients hospitalized with respiratory infections or Kaposi's sarcoma were diagnosed with histoplasmosis via nested PCR [56]. The majority of reported histoplasmosis cases with HIV coinfection have been caused by
H. capsulatum var. capsulatum; however, H. capsulatum var. duboisii is being increasingly recognized in HIV coinfected patients and has been shown to cause disseminated disease in this population [46, 49, 57-59].

Within Asia, Histoplasma has been known to be present in certain areas for many years [60]. Histoplasma was first isolated from soil in Malaysia in 1963, and Randhawa reviewed 30 possible autochthonous cases from India, Malaysia, Indonesia, Singapore, Thailand, Vietnam, and Japan in 1970 [61, 62]. There have been 144 cases of histoplasmosis recorded from 1954 through 2017 in India with the majority of reports from West Bengal, Assam, Bihar, Delhi, 


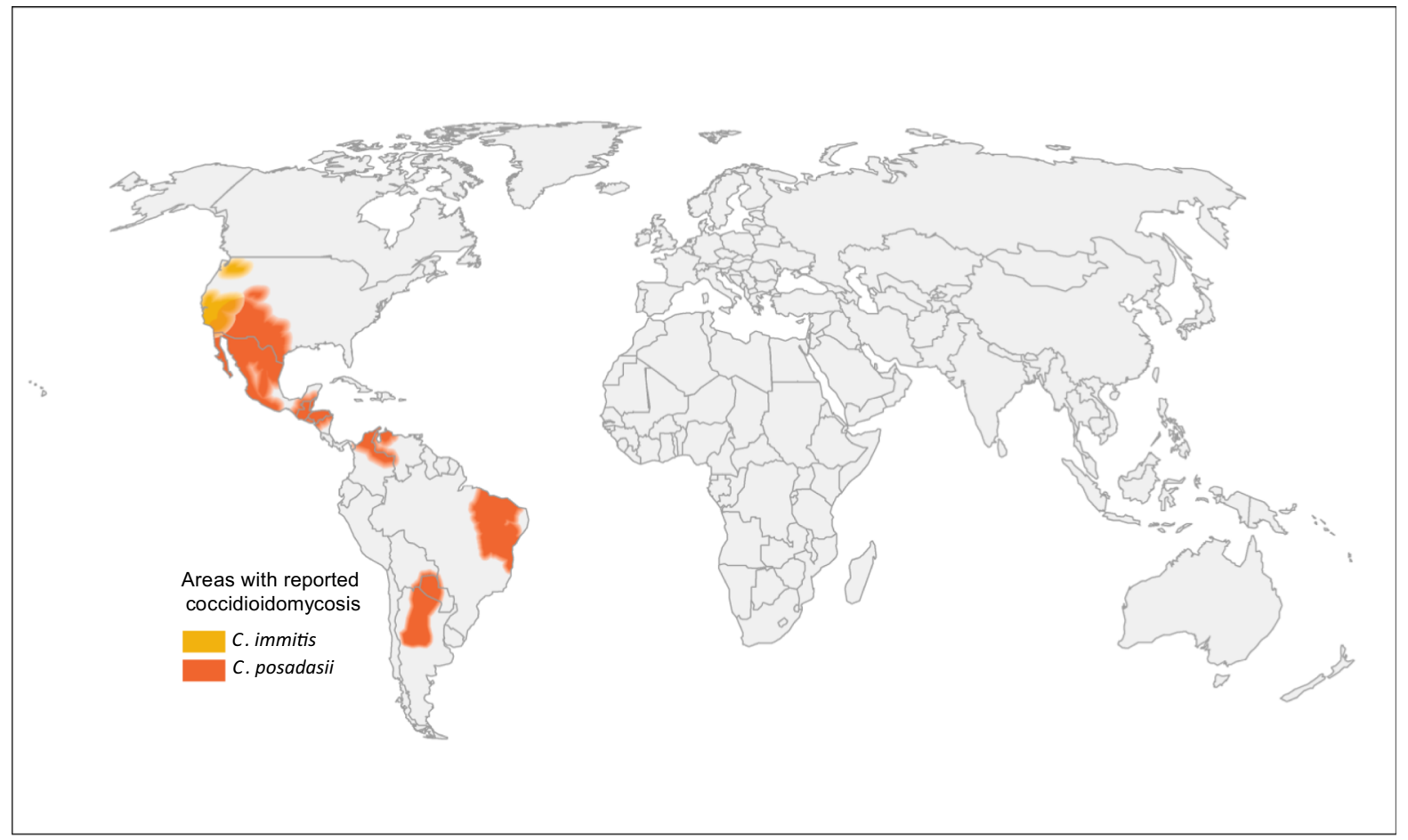

Fig. 2 World map estimating regions with coccidioidomycosis based on literature review

Haryana, Punjab, and Uttar Pradesh; as in many other settings, histoplasmosis is felt to be underdiagnosed in this country [63-65]. Histoplasmin sensitivities in Kolkata and Delhi range from 4.7-12.3\% [61]. Histoplasmin sensitivity in Bangladesh was found to be $17.9 \%$ with 16 reported cases of histoplasmosis in the medical literature from 1982 to 2013 [66, 67]. One study found histoplasmin positivity in China of $9.0 \%$ overall with higher values in Hunan and Jiangsu provinces [68]. A review of 300 cases of histoplasmosis in China from 1990-2011 (257 disseminated, $22 \%$ HIV infected) found that $75 \%$ of the cases were from regions along the Yangtze River in southeastern China, with all but 17 cases thought to be autochthonous [69]. Moreover, the use of bat guano as an herbal medicine may increase the risk of acquiring histoplasmosis in endemic areas [70]. In Japan, histoplasmin sensitivity is negligible (except in those exposed to imported soils) and local bat guano does not contain Histoplasma [61, 71]. The majority of cases of histoplasmosis in Southeast Asia have been reported from Thailand, where 1253 cases of disseminated histoplasmosis among HIV-infected persons were reported to the Ministry of Public Health from
1984 to 2010 [72]. Histoplasmin sensitivity in Thailand is as high as $34.4 \%$ in south and central Thailand and as low as $4.8 \%$ in north and northeast Thailand, although it is hypothesized that this may be an overestimation of true exposure due to cross-reactivity with Talaromyces marneffei antigen, which is also present in the region [54, 73]. A study of Burmese and Hmong refugees residing in Thailand found only 2/199 with seropositivity for anti-Histoplasma IgG [54]. Histoplasmin sensitivity in adults ranged from 9 to $12 \%$ in Indonesia and Malaysia and as high as $26 \%$ in the Philippines with cases reported in each of these countries [74-79]. Additional data suggest histoplasmin positivity of greater than $50 \%$ in parts of Myanmar and additional cases of histoplasmosis from Laos, Cambodia, Vietnam, Indonesia, Malaysia, Myanmar, the Philippines, and Singapore [60, 80-96]. Scattered cases of autochthonous histoplasmosis have been reported in Australia dating back to 1948 , and $H$. capsulatum has been isolated from fowl yards and caves within the country [97, 98]. An analysis of 63 proven histoplasmosis cases deemed 41 to have been acquired locally, primarily in Queensland and New South Wales which have large areas of 


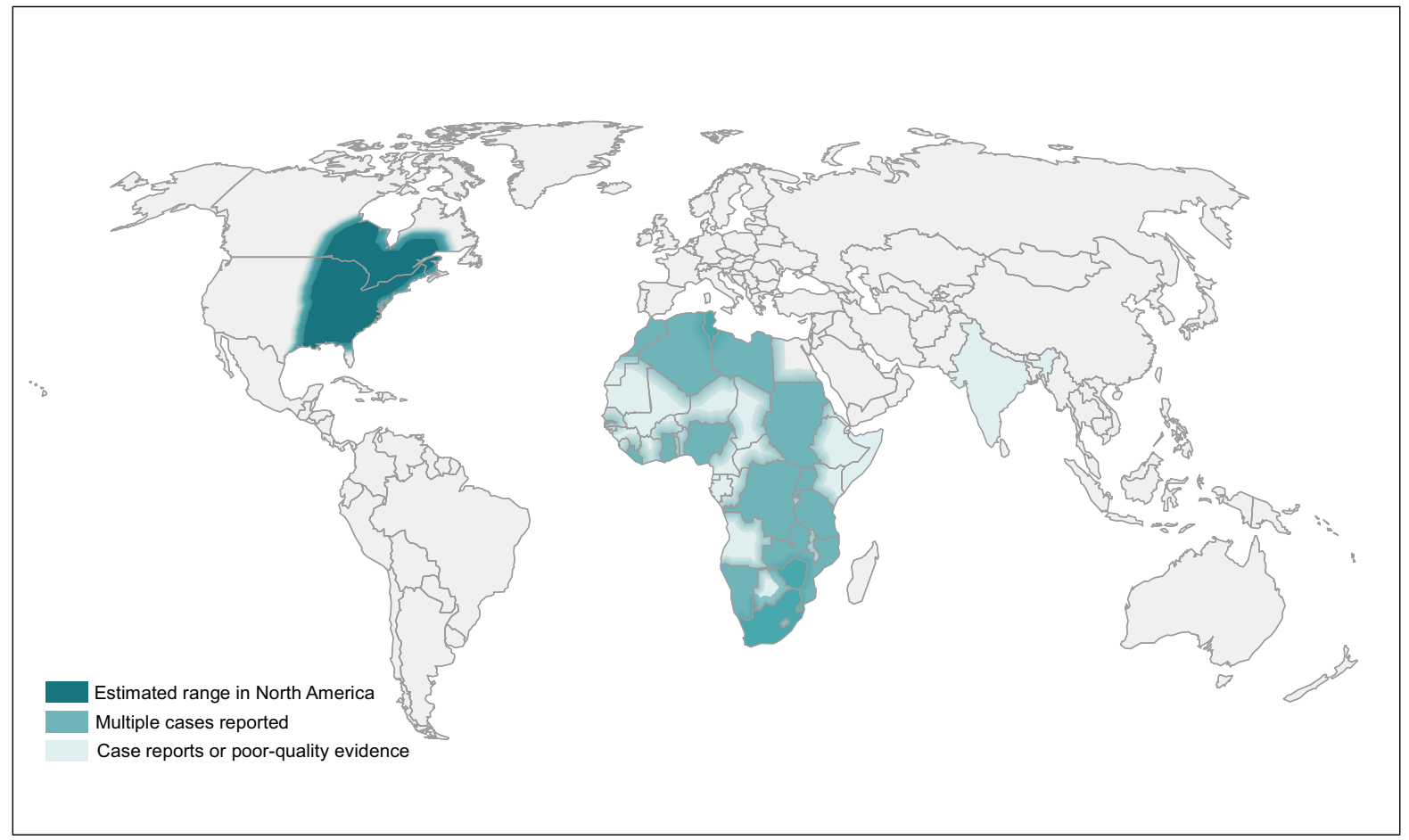

*Not that this map is specific to Blastomyces dermatitidis complex; other species, such as Blastomyces helicus are not included.

Fig. 3 World map estimating regions most likely to have blastomycosis* based on literature review

tropical and subtropical environments [99]. Recently, the first Middle Eastern autochthonous case was diagnosed in Israel [100].

In Europe, histoplasmosis is predominantly an imported disease [101]. In a review of 118 proven or probable histoplasmosis cases in Europe over a fiveyear period, Ashbee and colleagues found that all but eight cases had a history of travel to or migration from an endemic area [102]. The majority of European autochthonous cases of histoplasmosis have been identified in Italy, and H. capsulatum has been isolated from soil in the Po River valley where higher histoplasmin skin test positivity rates of $1.2 \%$ occur [103-109]. Ashbee's review also identified one case from Germany, where histoplasmosis has been diagnosed in badgers and hedgehogs [110, 111], and Turkey, where two other presumed autochthonous cases have been published $[112,113]$.

Our understanding of the distribution has improved such that rather than seeing histoplasmosis as a disease of the Central USA and parts of Central and South America, the map shown in Fig. 1 better reflects our current understanding of histoplasmosis endemicity. Histoplasmosis is truly endemic in much of the world. Further, in most settings, histoplasmosis is presumed to be underdiagnosed due to lack of available diagnostic tests and/or clinician awareness, or due to misdiagnosis.

\section{Coccidioidomycosis}

Coccidioidomycosis (Valley Fever) is caused by two epidemiologically and genetically diverse species, $C$. immitis and C. posadasii [34, 114-120]. C. immitis was first discovered in 1892 in Buenos Aires and misidentified as a protozoan; years later, it was correctly identified as a fungus [34, 121-124]. In 1957, Edwards et al. used skin testing to delineate the endemic areas within the USA $[6,121]$. Subsequently, public health surveillance as well as various serological and molecular methods have been utilized to help improve understanding of the geographic distribution of coccidioidomycosis within the USA [119, 125-127]. In 2002, Fisher et al. isolated two 
Table 3 Areas of endemicity for Paracoccidioides species

\begin{tabular}{|c|c|}
\hline Region/Species & Basis of endemicity \\
\hline \multicolumn{2}{|l|}{ P. brasiliensis } \\
\hline \multicolumn{2}{|l|}{ South America } \\
\hline \multicolumn{2}{|l|}{ Brazil } \\
\hline Sao Paulo & Multiple reports ranging from $1-1219$ cases during $1960-2012$ \\
\hline$[253,254,257,324-326]$ & Two studies reporting 83-444 cases during 1978-2012 \\
\hline Espírito Santo [233, 253] & Multiple reports during $1978-2012$ ranging from 3-36 cases \\
\hline Rio de Janeiro [253, 327, 328] & Multiple reports during 1978-2009 ranging from 50-252 cases \\
\hline Minas Gerais [252-254, 257, 329] & Two reports during 1988-2012, 3 and 2163 cases \\
\hline Rondônia [232, 257] & Two reported cases (1988-1996); confirmation based on serology or histopathology \\
\hline Mato Grosso [257] & Two reports during $1978-2012$ of 1 and 30 cases \\
\hline Bahia $[253,257]$ & One human case and 280 cases in cattle. \\
\hline Mato Grosso do Sul $[257,330]$ & Multiple reports ranging from $1-102$ human cases \\
\hline Paraná $[257,331,332]$ & Two reports of 61-123 human cases during 1966-2009 \\
\hline Rio Grande do Sul $[333,334]$ & Endemicity based on positive skin tests in 52/455 humans in one study \\
\hline Argentina & One case series of 22 human cases \\
\hline Corrientes [240] & Endemicity based on positive skin test in $28 / 275$ humans \\
\hline Formosa [335] & \\
\hline \multicolumn{2}{|l|}{ Venezuela: } \\
\hline \multicolumn{2}{|l|}{ San Felix city, Bolivar [336] } \\
\hline \multicolumn{2}{|l|}{ North America } \\
\hline Mexico & 51 human cases reported during 1972-2012 \\
\hline Gulf of Mexico [258] & 18 human cases reported during $1972-2012$ \\
\hline \multicolumn{2}{|l|}{ Pacific littoral [258] } \\
\hline \multicolumn{2}{|l|}{ P. lutzii } \\
\hline South America Brazil, Para [255] & Two human cases; confirmation based on phylogenetic analysis \\
\hline \multicolumn{2}{|l|}{ Unspecified Paracoccidioides species } \\
\hline \multicolumn{2}{|l|}{ South America } \\
\hline \multicolumn{2}{|l|}{ Brazil } \\
\hline Amazonas [337] & NA \\
\hline Para (284) & NA \\
\hline Acre [337] & NA \\
\hline Rondonia [337] & NA \\
\hline Federal Territory of Roraima & NA \\
\hline$[337]$ & Twenty-nine reported human cases during 2004-2010 \\
\hline Maranhao [338] & Outbreak with report of eight human cases 2015-2016 \\
\hline Rio de Janeiro [249] & One human case report, confirmed on histopathology \\
\hline Minas Gerais [241] & One human case report; article is in Japanese, and information regarding diagnosis is not \\
\hline Bolivia [231] & available. \\
\hline
\end{tabular}

$N A$ information not available

distinct pathogenic species based on phylogenetic analyses: C. immitis and C. posadasii [128]. C. immitis is primarily found in the Central Valley of California but has now been found as far north as eastern Washington state [119, 129-134]. C. posadasii, is found in the desert areas of Arizona, Texas, Utah, 
Table 4 Areas of Talaromyces marneffei endemicity

\begin{tabular}{|c|c|}
\hline Region & Basis of endemicity \\
\hline \multicolumn{2}{|l|}{ Republic of China } \\
\hline Guangxi $[272,277,339]$ & Multiple reports ranging from 8-109 human cases \\
\hline $\begin{array}{l}\text { Other provinces } \\
{[276,340-342]}\end{array}$ & Multiple reports ranging from 1-668 human cases, 1984-2017 \\
\hline Taiwan $[282,343-345]$ & Multiple reports ranging from $1-35$ cases \\
\hline Hong Kong [346-353] & Multiple reports ranging from $1-47$ cases \\
\hline \multicolumn{2}{|l|}{ Thailand } \\
\hline Chiang Mai $[268,354]$ & Multiple reports in HIV-infected patients ranging from 80-1843 cases during 1990-2004 \\
\hline Chiang Ray [355] & One case report in an Italian man based on microbiologic confirmation \\
\hline Khon Kaen [356] & $\begin{array}{l}10.6 \% \text { of fungal isolates collected from patients with invasive fungal infections during 2006-2011 } \\
\text { were Talaromyces marneffei }\end{array}$ \\
\hline & $\begin{array}{l}\text { One case report in a traveler in Greenland and Denmark from Thailand based on microbiologic } \\
\text { confirmation }\end{array}$ \\
\hline \multicolumn{2}{|l|}{ Vietnam } \\
\hline $\begin{array}{l}\text { Ho Chi Minh City } \\
\text { [287, 358-360] }\end{array}$ & $\begin{array}{l}\text { Multiple reports ranging from } 1-719 \text { cases } \\
\text { One case report based on microbiologic confirmation }\end{array}$ \\
\hline Tay Ninh [287] & One case report based on microbiologic confirmation \\
\hline $\begin{array}{l}\text { Dong Nai [287] } \\
\text { Kon Tum [287] }\end{array}$ & One case report based on microbiologic confirmation \\
\hline \multicolumn{2}{|l|}{ India } \\
\hline Manipur $[271,280,361]$ & Multiple reports ranging from $1-46$ cases \\
\hline Laos $[283,362]$ & Two reported cases based on microbiologic confirmation \\
\hline Myanmar [286] & One case report based on microbiologic confirmation \\
\hline
\end{tabular}

$N R$ not reported

Table 5 Emergomyces species by report locations

\begin{tabular}{|c|c|}
\hline Species & Case report locations \\
\hline $\begin{array}{c}\text { Es. africanus } \\
{[292,293]}\end{array}$ & South Africa \\
\hline $\begin{array}{l}\text { Es. pasteurianus } \\
\text { [294-299] }\end{array}$ & $\begin{array}{l}\text { Italy, Spain, the Netherlands, France, } \\
\text { India, China, South Africa, and } \\
\text { Uganda }\end{array}$ \\
\hline $\begin{array}{c}\text { Es. canadensis } \\
{[299,300]}\end{array}$ & Canada, USA \\
\hline Es. orientalis [301] & China \\
\hline $\begin{array}{c}\text { Es. europaeus } \\
{[290,302]}\end{array}$ & Germany \\
\hline
\end{tabular}

Mexico, and Central and South America [6, 133, 135-140]. However, there is geographic overlap between the two species in Southern California [122].

Southern Arizona and the San Joaquin Valley region in California have long been identified as hyperendemic areas, and these states account for $95 \%$ of all reported cases of coccidioidomycosis within the USA [141-144]. Although most cases are not associated with outbreaks, they typically involve disruption of the soil, including military maneuvers, construction work, earthquakes, landslides, and armadillo-hunting expeditions [145-149]. Some of the highest rates of coccidioidomycosis have occurred in people incarcerated in some of the prisons in California's Central Valley, and health officials have implemented policies to reduce risk and severe disease in these populations $[143,150,151]$. Interestingly, the incidence of coccidioidomycosis seems to be rising nationally during the last couple of decades in both endemic and non-endemic regions, and a total of 95,317 cases were reported between 2011 and 2017; while the incidence decreased in Arizona to 101 per 100,000 persons in 2017 from 261 in 2011, the incidence increased in California to 18.2 from 15.7 during the same time period [152]. The Centers for Disease 
Control and Prevention (CDC) reported a 58\% increase in coccidioidomycosis incidence in Arizona from October 2017 to March 2018 compared to the preceding years, and California saw the highest year on record in 2017. Turabelidze et al. reported a fivefold increase in the incidence of cases in Missouri from 0.05 per 100,000 population in 2004 to 0.28 per 100,000 in 2013 , with about a quarter of the cases either having no reported travel to the known endemic areas or no travel history [139, 153]. Meanwhile, a surveillance study in 14 states by Benedict et al. in 2016 identified Utah, Nevada, and New Mexico as low endemic areas compared to 11 other states including Missouri that were deemed non-endemic [135]. The study also highlighted the need for increased awareness of coccidioidomycoses in areas of low endemicity to avoid delay in its accurate diagnosis [135].

While coccidioidomycosis is a reportable disease within 26 states plus the District of Columbia as of February 2019 (Table 2), it is not a notifiable disease in the other 24 US states or in Latin America (with the exception of Argentina) [132, 154, 155]. In 1944, Gonzales-Ochoa was the first to conduct skin testing in Sonora and Baja California demonstrating 16\% reactivity rates [156]. In 1961, three endemic zones were recognized in a systematic study in Mexico: Northern zone (bordering the USA and including Baja California, Sonora, Chihuahua, Coahuila, Nuevo Leon, and Tamaulipas); Pacific Littoral Zone (extending southeast from the Northern Zone to Michoacán), and the Central zone (extending from the northeastern border of Coahuila and ending at the Michoacán border) [156]. Skin testing has thus been used to establish the endemic areas within Mexico with the highest proportion of reactors in the states of Baja California, Sonora, Sinaloa, Nuevo León, Coahuila, Tamaulipas and Chihuahua in the northwest [156, 157]. However, with lack of reporting and diagnostic capability, very little is known about current endemic areas. This translates to a dearth of knowledge regarding the endemic areas within the region and a reliance on published cases [34, 35, 145, 157, 158].

Within South America, numerous geographically isolated areas of endemicity have been discovered including the northeastern areas of Colombia; Zulia, Lara, and Falcon states in Venezuela; the Chaco region in Argentina and Paraguay including the provinces of Catamarca, La Rioja, and San Luis; and the Piaui, Maranhao, Ceara, and Bahai states of Brazil
[123, 155, 157]. In Central America, skin testing was first conducted by Andrade in 1945, reporting a low prevalence of reactors in Guatemala [159]. In 1953, Trejos et al. reported the first case in a resident of Honduras, and conducted skin testing the same year to establish endemicity in the Comayagua Valley of Honduras [160]. Since then, areas of endemicity have been identified in the Montague Valley of Guatemala and the Comayagua Valley of Honduras based on case reports [161]. Laniado-Laborín et al. and Negroni et al. also propose endemicity in Bolivia [121, 162, 163]. Figure 2 describes the geographic distribution of C. immitis and C. posadasii worldwide.

\section{Blastomycosis}

Blastomyces dermatitidis, including the more recently described cryptic species B. gilchristi (together referred to herein as B. dermatitidis species complex), and $B$. helicus cause disease in humans and animals via inhalation of airborne spores $[6,14,164-171]$. The mycelial form of the fungus primarily dwells in wooded land with damp soil near lakes, waterways and rivers [164, 167, 171-175]. Excavation and construction in endemic areas have been identified as risk factors for disease acquisition [176]. B. dermatitidis species complex is endemic in the mid-west, southeast, east and south-central USA; northwest Ontario, Quebec, Manitoba and Saskatchewan in Canada; central, eastern and southern Africa; and India $[6,7,28,164,166,167,177-185]$. Figure 3 shows the geographic distribution of $B$. dermatitidis species complex worldwide.

Much of the epidemiological data for blastomycosis have been obtained from reports in North America, with fewer reports from Africa and the Asia-Pacific region [181-184, 186-191]. As of February 2019, blastomycosis is only reportable in five states within the USA (Table 2), and while it used to be reportable in Ontario, Canada that has not been the case since 1989 [192]. The lack of mandatory public reporting coupled with the paucity of reliable tests for prior exposure has hindered the epidemiologic understanding of blastomycosis, unlike coccidioidomycosis and histoplasmosis [7, 166, 167, 171, 193-197].

Within the USA, Mississippi has historically had the highest prevalence, while incidence of hospitalizations involving blastomycosis was the highest in Arkansas, Illinois, Kentucky, Tennessee, and Wisconsin 
[170, 198, 199]. Incidence rates in the hyperendemic areas surrounding Mississippi and Ohio River Valleys vary from 0.5-100/100,000 [171]. Thus far, blastomycosis has been reported in Alabama, Arkansas, Colorado, Georgia, Illinois, Indiana, Iowa, Kentucky, Louisiana, Michigan, Minnesota, Mississippi, Missouri, Nebraska, New York, North Carolina, North Dakota, Ohio, Pennsylvania, South Carolina, South Dakota, Tennessee, Texas, Vermont, West Virginia, and Wisconsin $[14,165,170,175,180,193,194,199-211]$. A number of these states clearly fall outside of the typically described endemic area, and it is unclear whether they truly belong to $B$. dermatitidis species complex or $B$. helicus (Fig. 3). Within Canada, blastomycosis has been reported in the provinces adjoining the Great Lakes including Manitoba, Ontario and Quebec [7, 179, 212-214]. More recently, Lohrenz et al. reported 15 cases of blastomycosis in southern Saskatchewan of which nine had never been to a known endemic region [215]. The endemicity of $B$. dermatitidis in Asia-Pacific region remains controversial [175, 177]. In India, the organism was first isolated from a bat in Delhi in 1982 and human case reports with pulmonary and cerebral lesions have been described; however, Savio and colleagues subsequently noted that previously reported cases had prior travel to an endemic area in the USA or poor quality of evidence confirming the disease [175, 177, 187-190, 216]. In Africa, B. dermatitidis has been primarily reported in Tunisia, South Africa and Zimbabwe although cases have been reported in individuals from Algeria, Libya, Sudan, Morocco, Gambia, Namibia, Mozambique, Zambia, Tanzania, Uganda, Rwanda, the Democratic Republic of Congo, Nigeria, Liberia, and Ghana; while majority of these cases have disease confirmation based on cultures or histopathology, the quality of evidence is poor for others [181-184, 191, 217-228].

Less is known about the distributions of B. helicus. $B$. helicus has been reported in western regions of North America including Alberta and Saskatchewan, Canada, as well as Colorado, Idaho, Montana, Nebraska, Northern California, Texas, and Utah in the USA [229].

Paracoccidioidomycosis

Paracoccidioidomycosis is a systemic mycosis caused by Paracoccidioides brasiliensis and
Paracoccidioides lutzii [230-241]. Paracoccidioidomycosis is a rare disease worldwide, but is a frequent AIDS-defining opportunistic infection in Latin America, and is now recognized as a neglected tropical disease by the World Health Organization [230, 231, 235, 239, 242-251]. P. brasiliensis is endemic in large parts of South America, with the greatest prevalence in southeast, south, and centralwest Brazil; Venezuela and Columbia, followed by northern Argentina, eastern Paraguay, and the Cuenca River valley in Ecuador [155, 230, 232, 235, 238, 239, 245, 246, 252-257]. Southern Mexico and Central America have lower rates but are also endemic [238, 258]. Because these data are inferred from case reports and retrospective studies of hospitalized patients, incidence rates are postulated to be higher [34, 155, 238, 239, 248, 253, 257]. Furthermore, climate change, human migration, the expansion of agricultural activities, and highway construction have affected the epidemiology of Paracoccidioides, which is now expanding from the south and southeast to the central-west and north regions of Brazil [238, 249, 259]. All cases of $P$. brasiliensis reported outside of endemic regions were acquired via travel to endemic areas [101, 238, 256, 260-263] (Table 3). $P$. lutzii was only recently identified as a new species by multi-locus sequencing studies, and is known to be endemic in central, mid-west, and northern Brazil, Ecuador, and Venezuela [34, 236, 238, 241, 264].

\section{Talaromycosis}

Talaromycosis is a common, AIDS-defining opportunistic infection in South and Southeast Asia [265-273]. Talaromyces marneffei (formerly Penicillium marneffei) is a soil dwelling fungus that causes disease in humans via inhalation or inoculation of conidia [270]. Di Salvo et al. described the first naturally acquired infection in a patient with Hodgkin's lymphoma in 1973 (the patient was in the USA but had been to Southeast Asia three years prior), and only a handful of cases were reported in Thailand until 1984 [274, 275]. Subsequently, alarmingly high incidence rates were observed in Southeast Asia in 1988, paralleling the HIV-AIDS epidemic [270].

T. marneffei is endemic in southwest China (particularly Guangxi province) but seems to be increasing in much of mainland China with 668 cases reported 
between 1984 and 2009 [268-270, 273, 276, 277]. Thailand, Hong Kong, northeastern India (particularly Assam and Manipur states), Taiwan, Laos, Cambodia, Malaysia, Myanmar, Indonesia and Vietnam are other endemic areas based on autochthonous case reports [266, 268-271, 273, 278-287] (Table 4). In China, 8\% of T. marneffei cases occur in healthy individuals; additionally, talaromycosis is an important presentation of adult-onset immunodeficiency syndrome, which is more common in Southeast Asia [288]. Interestingly, case reports of talaromycosis in Togo and Ghana, in West Africa, have occurred without known travel to endemic regions [273].

\section{Emergomycosis}

Emergomycosis is a disease caused by infection with thermally dimorphic fungi in the recently described genus Emergomyces. The earliest member of the genus, Es. pasteurianus, was originally described in 1998 in the genus Emmonsia based on genetic and phenotypic similarities to Emmonsia parva (since reclassified as Blastomyces parvus) and Ea. crescens. It remained the outlier in the genus because, unlike $E a$. parva and Ea. crescens, the thermodependant tissue phase was characterized by small, narrow budding yeasts in contrast to large, non-replicating adiaspores. The relevance and taxonomic placement of $E a$. pasteuriana, as it was then known, was uncertain until 15 years later, with publication of a report of South African patients with advanced HIV disease who developed disseminated disease caused by a novel fungus [289]. Those isolates were closely related to Ea. pasteuriana, and eventually prompted a re-examination of global fungal collections for atypical Emmonsia-like isolates. What ensued was a taxonomic overhaul of the Ajellomycetaceae, including Emmonsia and Blastomyces, and the creation of a new genus, Emergomyces [290, 291].

There are currently five species of Emergomyces (Table 5). Es. africanus has been implicated in over 80 cases in South Africa, where it is the most frequently diagnosed endemic mycosis [292, 293]. Es. pasteurianus has been described in Italy, Spain, the Netherlands, France, India, China, South Africa, and Uganda. Although two cases from the Netherlands were associated with travel to Morocco and Iraq, other European cases had no significant travel history reported [294-299]. Es. canadensis has been described in Saskatchewan, Canada, and in Colorado and New Mexico in the USA. Only one case of infection due to Es. orientalis has been described, in China [299-301]. Es. europaeus was reported to cause infection just once, when it was isolated from the lung of a German patient on chronic corticosteroids [290, 302].

\section{Conclusions}

Endemic mycoses cause significant morbidity and mortality in immunocompetent and immunocompromised individuals worldwide and each has its own evolving regions of endemicity. Diagnosis is often missed or delayed, especially outside the areas of endemicity, due to a lack of awareness of the pathogen which is due at least in part to a scarcity of data on its geographic distribution [7].

This review summarizes the recent shifts and expansions observed in the prevalence of some of the endemic fungi worldwide. We hypothesize that these changes result from human migration, agricultural practices, occupational exposures, deforestation, soil movement, and climate change [238]. Ongoing disease surveillance is essential to understand these diseases, and wider public health reporting could help detect locally acquired cases and track changes in spatial and temporal distribution. Closer observation would allow for better understanding of the epidemiology of these fungi and improve clinical awareness. Ongoing environmental and epidemiological studies are warranted to accurately estimate the incidences and geographic distribution of these fungi worldwide.

In 1971 Ajello wrote, "Information on the prevalence and incidence of histoplasmosis is extensive when compared with that available for the other mycoses. Much remains to be learned, however, before we have the full picture of its impact on the welfare of human beings" [303]. Truly, despite many reports, the full picture of the impact of histoplasmosis on the welfare of humans remains unclear, in part, because the condition is underfunded and neglected. The same is true to a far greater degree for other endemic fungi.

Acknowledgements The authors would like to thank Dr. George Sarosi for his thoughtful comments on this manuscript. 
Dr. Bahr is supported by the National Institute of Neurologic Diseases and Stroke (K23NS110470).

\section{Compliance with Ethical Standards}

Conflict of interest The authors declare no conflict of interest.

Human and Animal Rights Preparation of this manuscript did not involve human or animal participants.

Informed Consent As no research participants were involved, no informed consent was required.

Open Access This article is licensed under a Creative Commons Attribution 4.0 International License, which permits use, sharing, adaptation, distribution and reproduction in any medium or format, as long as you give appropriate credit to the original author(s) and the source, provide a link to the Creative Commons licence, and indicate if changes were made. The images or other third party material in this article are included in the article's Creative Commons licence, unless indicated otherwise in a credit line to the material. If material is not included in the article's Creative Commons licence and your intended use is not permitted by statutory regulation or exceeds the permitted use, you will need to obtain permission directly from the copyright holder. To view a copy of this licence, visit http://creativecommons.org/licenses/by/4.0/.

\section{References}

1. Pfaller MA, Diekema DJ. Epidemiology of invasive mycoses in North America. Crit Rev Microbiol. 2010;36(1):1-53.

2. Vallabhaneni $S$, et al. The global burden of fungal diseases. Infect Dis Clin North Am. 2016;30(1):1-11.

3. Wheat J. Endemic mycoses in AIDS: a clinical review. Clin Microbiol Rev. 1995;8(1):146-59.

4. Hage CA, Knox KS, Wheat LJ. Endemic mycoses: overlooked causes of community acquired pneumonia. Respir Med. 2012;106(6):769-76.

5. Benedict K, Beer KD, Jackson BR. Histoplasmosis-related healthcare use, diagnosis, and treatment in a commercially insured population, United States. Clin Infect Dis. 2019. https://doi.org/10.1093/cid/ciz324.

6. Benedict $\mathrm{K}$, et al. Mycotic infections acquired outside areas of known endemicity, United States. Emerg Infect Dis. 2015;21(11):1935-41.

7. Brown EM, et al. Epidemiology and geographic distribution of blastomycosis, histoplasmosis, and coccidioidomycosis, Ontario, Canada, 1990-2015. Emerg Infect Dis. 2018;24(7):1257-66.

8. Buitrago MJ, et al. Histoplasmosis and paracoccidioidomycosis in a non-endemic area: a review of cases and diagnosis. J Travel Med. 2011;18(1):26-33.

9. Haselow D, et al. Geographic distribution of endemic fungal infections among older persons, United States. Emerg Infect Dis. 2012;18(2):360-1.
10. Maiga AW, et al. Mapping histoplasma capsulatum exposure, United States. Emerg Infect Dis. 2018;24(10):1835-9.

11. Antinori S. Histoplasma capsulatum: more widespread than previously thought. Am J Trop Med Hyg. 2014;90(6):982-3.

12. Bahr NC, et al. Histoplasmosis infections worldwide: thinking outside of the Ohio River valley. Curr Trop Med Rep. 2015;2(2):70-80.

13. McKinsey DS, Pappas PG. Histoplasmosis: time to redraw the map and up our game. Clin Infect Dis. 2019. https://doi. org/10.1093/cid/ciz327.

14. Baddley JW, et al. Geographic distribution of endemic fungal infections among older persons, United States. Emerg Infect Dis. 2011;17(9):1664-9.

15. Kauffman CA. Histoplasmosis: a clinical and laboratory update. Clin Microbiol Rev. 2007;20(1):115-32.

16. Scantlebury CE, et al. Development and evaluation of a molecular diagnostic method for rapid detection of Histoplasma capsulatum var. farciminosum, the causative agent of epizootic lymphangitis, equine clinical samples. J Clin Microbiol. 2016;54(12):2990-9.

17. Tamura M, et al. Phylogenetic characterization of Histoplasma capsulatum strains based on ITS region sequences, including two new strains from Thai and Chinese patients in Japan. Nihon Ishinkin Gakkai Zasshi. 2002;43(1):11-9.

18. Darling ST. A Protozoön general infection producing pseudotubercles in the lungs and focal necroses in the liver, spleen and lymphnodes. JAMA. 1906;46(17):1283-5.

19. Wheat LJ, et al. Histoplasmosis. Infect Dis Clin North Am. 2016;30(1):207-27.

20. Wheat LJ, et al. Clinical practice guidelines for the management of patients with histoplasmosis: 2007 update by the Infectious Diseases Society of America. Clin Infect Dis. 2007;45(7):807-25.

21. Sepulveda VE, et al. Genome sequences reveal cryptic speciation in the human pathogen Histoplasma capsulatum. MBio. 2017;8(6):e01339-17.

22. Armstrong PA, et al. Multistate epidemiology of histoplasmosis, United States, 2011-2014. Emerg Infect Dis. 2018;24(3):425-31.

23. Bellman B, et al. Cutaneous disseminated histoplasmosis in AIDS patients in south Florida. Int $\mathrm{J}$ Dermatol. 1997;36(8):599-603.

24. Hott JS, et al. Intramedullary histoplasmosis spinal cord abscess in a nonendemic region: case report and review of the literature. J Spinal Disord Tech. 2003;16(2):212-5.

25. Huang CT, et al. Disseminated histoplasmosis in the acquired immunodeficiency syndrome. Report of five cases from a nonendemic area. Arch Intern Med. 1987;147(6):1181-4.

26. Nett RJ, et al. Histoplasmosis in Idaho and Montana, USA, 2012-2013. Emerg Infect Dis. 2015;21(6):1071-2.

27. Burek-Huntington KA, Gill V, Bradway DS. Locally acquired disseminated histoplasmosis in a northern sea otter (Enhydra lutris kenyoni) in Alaska, USA. J Wildl Dis. 2014;50(2):389-92.

28. Dufresne SF, et al. Serious fungal infections in Canada. Eur J Clin Microbiol Infect Dis. 2017;36(6):987-92. 
29. Nicolle L, et al. Invasive fungal infections in Canada from 1992 to 1994. Can J Infect Dis. 1998;9(6):347-52.

30. Dingle $\mathrm{T}$, et al. Histoplasmosis Acquired in Alberta, Canada, 2011-2018. Open Forum Infectious Diseases. 2019;6(Suppl 2):S631.

31. Anderson H, et al. Histoplasmosis cluster, golf course, Canada. Emerg Infect Dis. 2006;12(1):163-5.

32. Adenis AA, et al. Burden of HIV-associated histoplasmosis compared with tuberculosis in Latin America: a modelling study. Lancet Infect Dis. 2018;18(10):1150-9.

33. Alvarez E, Amaro J, Villavicencio L. Histoplasma capsulatum: an emerging agent in Chile? Rev Chilena Infectol. 2018;35(3):309-11.

34. Colombo AL, et al. Epidemiology of endemic systemic fungal infections in Latin America. Med Mycol. 2011;49(8):785-98.

35. Corzo-Leon DE, Armstrong-James D, Denning DW. Burden of serious fungal infections in Mexico. Mycoses. 2015;58(Suppl 5):34-44.

36. Lopez Daneri AG, et al. [Disseminated histoplasmosis in patients with AIDS. Buenos Aires, 2009-2014]. Medicina (B Aires). 2016;76(6):332-337.

37. Mora DJ, dos Santos CT, Silva-Vergara ML. Disseminated histoplasmosis in acquired immunodeficiency syndrome patients in Uberaba, MG, Brazil. Mycoses. 2008;51(2):136-40.

38. Putot A, et al. HIV-associated disseminated histoplasmosis in western French Guiana, 2002-2012. Mycoses. 2015;58(3):160-6.

39. Karimi K, et al. Differences in histoplasmosis in patients with acquired immunodeficiency syndrome in the United States and Brazil. J Infect Dis. 2002;186(11):1655-60.

40. Falci DR, et al. Histoplasmosis, an underdiagnosed disease affecting people living with HIV/AIDS in Brazil: results of a multicenter prospective cohort study using both classical mycology tests and histoplasma urine antigen detection. Open Forum Infect Dis. 2019;6(4):ofz073.

41. Armstrong PA, et al. Outbreak of severe histoplasmosis among tunnel workers-dominican republic, 2015. Clin Infect Dis. 2018;66(10):1550-7.

42. Senechal A, et al. Imported pulmonary histoplasmosis in three French cavers after a trip to Cuba. J Travel Med. 2012;19(1):64-5.

43. Gugnani HC, Denning DW. Estimated burden of serious fungal infections in Jamaica by literature review and modelling. West Indian Med J. 2015;64(3):245-9.

44. Nacher M, et al. AIDS-related disseminated histoplasmosis in the greater Caribbean: how frequent is it? Aids. 2006;20(6):951-2.

45. Denning DW, Gugnani HC. Burden of serious fungal infections in Trinidad and Tobago. Mycoses. 2015;58(Suppl 5):80-4.

46. Oladele RO, et al. Histoplasmosis in Africa: an emerging or a neglected disease? PLoS Negl Trop Dis. 2018;12(1):e0006046.

47. Coulanges P. [Large-form histoplasmosis (H. duboisii) in Madagascar (apropos of 3 cases)]. Arch Inst Pasteur Madagascar. 1989;56(1):169-74.

48. Lofgren SM, et al. Histoplasmosis among hospitalized febrile patients in northern Tanzania. Trans R Soc Trop Med Hyg. 2012;106(8):504-7.
49. Valero C, et al. African histoplasmosis: new clinical and microbiological insights. Med Mycol. 2018;56(1):51-9.

50. Oladele RO, et al. Prior subclinical histoplasmosis revealed in Nigeria using histoplasmin skin testing. PLoS ONE. 2018;13(5):e0196224.

51. Muotoe-Okafor FA, Gugnani HC, Gugnani A. Skin and serum reactivity among humans to histoplasmin in the vicinity of a natural focus of Histoplasma capsulatum var. duboisii. Mycopathologia. 1996;134(2):71-4.

52. Nuti M, et al. Histoplasmosis diffusion in Somalia: study of skin-test and serological survey. Biochem Exp Biol. 1979;15(2):111-7.

53. Bezjak V, Farsey SJ. Prevalence of skin sensitivity to histoplasmin and coccidioidin in varous Ugandan populations. Am J Trop Med Hyg. 1970;19(4):664-9.

54. Bahr NC, et al. Seroprevalence of histoplasmosis in somali, burmese, and hmong refugees residing in Thailand and Kenya. J Immigr Minor Health. 2018;20(2):334-8.

55. Bahr NC, et al. Seroprevalence of histoplasmosis in Kampala, Uganda. Med Mycol. 2016;54(3):295-300.

56. Sacarlal J, Denning DW. Estimated burden of serious fungal infections in mozambique. $J$ Fungi (Basel). 2018;4(3):75. https://doi.org/10.3390/jof4030075.

57. Loulergue $P$, et al. Literature review and case histories of Histoplasma capsulatum var. duboisii infections in HIVinfected patients. Emerg Infect Dis. 2007;13(11):1647-52.

58. Gumbo T, et al. Clinicopathological features of cutaneous histoplasmosis in human immunodeficiency virus-infected patients in Zimbabwe. Trans $\mathrm{R}$ Soc Trop Med Hyg. 2001;95(6):635-6.

59. Ramdial PK, et al. Disseminated cutaneous histoplasmosis in patients infected with human immunodeficiency virus. J Cutan Pathol. 2002;29(4):215-25.

60. Baker J, et al. Mapping histoplasmosis in South East Asia-implications for diagnosis in AIDS. Emerg Microbes Infect. 2019;8(1):1139-45.

61. Randhawa HS. Occurrence of histoplasmosis in Asia. Mycopathol Mycol Appl. 1970;41(1):75-89.

62. Ponnampalam J. Isolation of Histoplasma Capsulatum from the soil of a cave in central Malaya. Am J Trop Med Hyg. 1963;12:775-6.

63. Goswami RP, et al. Histoplasmosis in eastern India: the tip of the iceberg? Trans $\mathrm{R}$ Soc Trop Med Hyg. 1999;93(5):540-2.

64. Mahajan VK, et al. Case report: histoplasmosis in Himachal Pradesh (India): an emerging endemic focus. Am J Trop Med Hyg. 2017;97(6):1749-56.

65. Patel AK, et al. Histoplasmosis in non-endemic NorthWestern part of India. Indian $\mathrm{J}$ Med Microbiol. 2018;36(1):61-4.

66. Gugnani $\mathrm{HC}$, et al. Burden of serious fungal infections in Bangladesh. Eur J Clin Microbiol Infect Dis. 2017;36(6):993-7.

67. Islam N, Sobhan MA. Sensitivity to histoplasmin, coccidioidin, blastomycin, and tuberculin in East Pakistan. Am J Trop Med Hyg. 1971;20(4):621-4.

68. Zhao B, et al. Epidemiological investigation of Histoplasma capsulatum infection in China. Chin Med J (Engl). 2001;114(7):743-6. 
69. Pan B, et al. Histoplasmosis: a new endemic fungal infection in China? Review and analysis of cases. Mycoses. 2013;56(3):212-21.

70. Wang Y, et al. Detection and phylogenetic characterization of a case of Histoplasma capsulatum infection in mainland China. Am J Trop Med Hyg. 2014;90(6):1180-3.

71. Kikuchi $\mathrm{K}$, et al. Is Histoplasma capsulatum a native inhabitant of Japan? Microbiol Immunol. 2008;52(9):455-9.

72. Norkaew T, et al. Detection of environmental sources of Histoplasma capsulatum in Chiang Mai, Thailand, by nested PCR. Mycopathologia. 2013;176(5-6):395-402.

73. Taylor RL, Duangmani C, Charoenvit Y. The geographic distribution of histoplasmin sensitivity in Thailand. Am J Trop Med Hyg. 1968;17(4):579-83.

74. Bulmer AC, Bulmer GS. Incidence of histoplasmin hypersensitivity in the Philippines. Mycopathologia. 2001;149(2):69-71.

75. Joe LK, et al. Histoplasmin sensitivity in Indonesia. Am J Trop Med Hyg. 1956;5(1):110-8.

76. Roy RN. Sensitivity to tuberculin, PPD-B and histoplasmin in the population of Sabah in East Malaysia. Med J Aust. 1971;1(6):317-21.

77. Batac MCR, Denning D. Serious fungal infections in the Philippines. Eur J Clin Microbiol Infect Dis. 2017;36(6):937-41.

78. Ohno $\mathrm{H}$, et al. An outbreak of histoplasmosis among healthy young Japanese women after traveling to Southeast Asia. Intern Med. 2010;49(5):491-5.

79. Sirait SP, Bramono K, Hermanto N. Correlation of CD4 counts with clinical and histopathological findings in disseminated histoplasmosis: a 10-year retrospective study. Int J Dermatol. 2017;56(9):926-31.

80. Anggorowati N, et al. Disseminated histoplasmosis in an Indonesian HIV-positive patient: a case diagnosed by fine needle aspiration cytology. Acta Med Indones. 2017;49(4):360-2.

81. Bellamy R, Sangeetha S, Paton NI. AIDS-defining illnesses among patients with HIV in Singapore, 1985-2001: results from the Singapore HIV Observational Cohort Study (SHOCS). BMC Infect Dis. 2004;4:47.

82. Bourgeois N, et al. Seven imported histoplasmosis cases due to Histoplasma capsulatum var. capsulatum: From few weeks to more than three decades asymptomatic period. J Mycol Med. 2011;21(1):19-23.

83. Bun Navy K, et al. The first reported cases of disseminated histoplasmosis in Cambodia, complicated by multiple opportunistic infections. Southeast Asian J Trop Med Public Health. 2005;36(5):1272-4.

84. Grosse G, Heise W, Staib F. Histoplasmosis of the skin as an initial opportunistic infection in AIDS. Dtsch Med Wochenschr. 1993;118(43):1555-60.

85. Jordan AS, et al. A budding surprise from the joint. Med J Aust. 2013;199(10):700-1.

86. Maydat L. The first case of generalized histoplasmosis in South Vietnam. Bull Soc Pathol Exot Filiales. 1962;55:35-9.

87. Mukherjee JJ, et al. Bilateral adrenal masses due to histoplasmosis. J Clin Endocrinol Metab. 2005;90(12):6725-6.
88. Murty OP. Cystic tumor of papillary muscle of heart: a rare finding in sudden death. Am J Forensic Med Pathol. 2009;30(2):201-3.

89. Navarro EE, et al. Disseminated histoplasmosis with unusual cutaneous lesions in a patient from the Philippines. Am J Trop Med Hyg. 1992;46(2):141-5.

90. Nissapatorn V, et al. Spectrum of opportunistic infections among HIV-infected patients in Malaysia. Southeast Asian J Trop Med Public Health. 2004;35(Suppl 2):26-32.

91. Pilsczek FH. Case histories of infectious disease management in developing countries: Phnom Penh and Kabul. Rev Soc Bras Med Trop. 2009;42(5):477-83.

92. Pineau $S$, et al. Contribution of molecular biology and Aspergillus Galactomannan antigen assay for the diagnosis of histoplasmosis. Med Mal Infect. 2010;40(9):541-3.

93. Radin DR. Disseminated histoplasmosis: abdominal CT findings in 16 patients. AJR Am J Roentgenol. 1991;157(5):955-8.

94. Supramaniam JM. The first reported case of broncholithiasis in Singapore. Singapore Med J. 1962;3:94-7.

95. Tan HJ, Cheong I, Muhaizan WM. Disseminated histoplasmosis in AIDS: a report of three patients. Med J Malaysia. 2000;55(2):259-62.

96. Tucker HA, Kvisselgaard N. Histoplasmin and tuberculin sensitivity in Burma; study of tests on 3,558 subjects. Bull World Health Organ. 1952;7(2):188-200.

97. O'Sullivan MV, et al. Histoplasmosis in Australia: a report of a case with a review of the literature. Aust Dent J. 2004;49(2):94-7.

98. Johnson DW, Derrick EH. Histoplasmosis; report of an Australian case. Med J Aust. 1948;2(18):518.

99. McLeod DS, et al. Histoplasmosis in Australia: report of 16 cases and literature review. Medicine (Baltimore). 2011;90(1):61-8.

100. Elias A, et al. Case report: histoplasmosis: first autochthonous case from Israel. Am J Trop Med Hyg. 2018;98(1):278-80.

101. Sabino R, et al. Serious fungal infections in Portugal. Eur J Clin Microbiol Infect Dis. 2017;36(7):1345-52.

102. Ashbee HR, et al. Histoplasmosis in Europe: report on an epidemiological survey from the European Confederation of Medical Mycology Working Group. Med Mycol. 2008;46(1):57-65.

103. Sotgiu G, et al. Histoplasma capsulatum: currence in soil from the Emilia-Romagna region of Italy. Science. 1965;147(3658):624.

104. Antinori S, et al. A case of fatal disseminated histoplasmosis of autochthonous origin in an Italian AIDS patient. Eur J Clin Microbiol Infect Dis. 1997;16(7):545-6.

105. Farina $\mathrm{C}$, et al. Imported and autochthonous histoplasmosis in Bergamo province, Northern Italy. Scand J Infect Dis. 2000;32(3):271-4.

106. Farina $\mathrm{C}$, et al. Imported and autochthonous histoplasmosis in Italy: new cases and old problems. Rev Iberoam Micol. 2005;22(3):169-71.

107. Romano C, et al. Case report. Primary cutaneous histoplasmosis in an immunosuppressed patient. Mycoses. 2000;43(3-4):151-4.

108. Sotgiu G, Mantovani A, Mazzoni A. Histoplasmosis in Europe. Mycopathol Mycol Appl. 1970;41(1):53-74. 
109. Confalonieri M, et al. Histoplasmin sensitivity among a student population in Crema, Po Valley, Italy. New Microbiol. 1994;17(2):151-3.

110. Jacobsen B, Baumgartner W, Bialek R. Disseminated histoplasmosis in a European hedgehog (Erinaceus europaeus) in Northern Germany. Mycoses. 2011;54(6):538-41.

111. Wohlsein P, et al. Histoplasmosis in two badgers (Meles meles) in northern Germany. Dtsch Tierarztl Wochenschr. 2001;108(6):273-6.

112. Turhan U, et al. A rare case in Turkey: pulmonary histoplasmosis. Eurasian J Pulmonol. 2016;18:116-8.

113. Saglam T. Histoplasmosis. Schweiz Med Wochenschr. 1946;76(45):1153-6.

114. Alvarado P, et al. Detection of Coccidioides posadasii from xerophytic environments in Venezuela reveals risk of naturally acquired coccidioidomycosis infections. Emerg Microbes Infect. 2018;7(1):46.

115. (CDC), C.f.D.C.a.P., Increase in reported coccidioidomycosis-United States, 1998-2011. MMWR Morb Mortal Wkly Rep. 2013;62(12):217-21.

116. Barker BM, et al. The population biology of coccidioides: epidemiologic implications for disease outbreaks. Ann N Y Acad Sci. 2007;1111:147-63.

117. Brilhante RS, et al. Genetic diversity of Coccidioides posadasii from Brazil. Med Mycol. 2013;51(4):432-7.

118. Brillhante RS, et al. Coccidioidomycosis in armadillo hunters from the state of Ceará. Brazil. Mem Inst Oswaldo Cruz. 2012;107(6):813-5.

119. Chow NA, et al. Development of an enzyme immunoassay for detection of antibodies against Coccidioides in dogs and other mammalian species. PLoS ONE. 2017;12(4):e0175081.

120. Ruddy BE, et al. Coccidioidomycosis in African Americans. Mayo Clin Proc. 2011;86(1):63-9.

121. Brown J, et al. Coccidioidomycosis: epidemiology. Clin Epidemiol. 2013;5:185-97.

122. Kirkland TN, Fierer J. Coccidioides immitis and posadasii. a review of their biology, genomics, pathogenesis, and host immunity. Virulence. 2018;9(1):1426-35.

123. Kollath DR, Miller KJ, Barker BM. The mysterious desert dwellers: Coccidioides immitis and Coccidioides posadasii, causative fungal agents of coccidioidomycosis. Virulence. 2019;10(1):222-33.

124. Parish JM, Blair JE. Coccidioidomycosis. Mayo Clin Proc. 2008;83(3):343-48; quiz 348-9.

125. Canteros CE, et al. Endemic fungal pathogens in a rural setting of Argentina: seroepidemiological study in dogs. Rev Iberoam Micol. 2010;27(1):14-9.

126. Duarte-Escalante E, et al. Molecular markers in the epidemiology and diagnosis of coccidioidomycosis. Rev Iberoam Micol. 2014;31(1):49-53.

127. Lindsley MD, et al. Evaluation of the specificity of two enzyme immunoassays for coccidioidomycosis by using sera from a region of endemicity and a region of nonendemicity. Clin Vaccine Immunol. 2015;22(10):1090-5.

128. Fisher MC, et al. Molecular and phenotypic description of Coccidioides posadasii sp. nov., previously recognized as the non-California population of Coccidioides immitis. Mycologia. 2002;94(1):73-84.
129. Cairns L, et al. Outbreak of coccidioidomycosis in Washington state residents returning from Mexico. Clin Infect Dis. 2000;30(1):61-4.

130. Litvintseva AP, et al. Valley fever: finding new places for an old disease: Coccidioides immitis found in Washington State soil associated with recent human infection. Clin Infect Dis. 2015;60(1):e1-3.

131. Marsden-Haug N, et al. Coccidioidomycosis acquired in Washington State. Clin Infect Dis. 2013;56(6):847-50.

132. McCotter OZ, et al. Update on the Epidemiology of coccidioidomycosis in the United States. Med Mycol. 2019;57(Suppl 1):S30-40.

133. Nguyen C, et al. Recent advances in our understanding of the environmental, epidemiological, immunological, and clinical dimensions of coccidioidomycosis. Clin Microbiol Rev. 2013;26(3):505-25.

134. Oltean HN, et al. Utility of whole-genome sequencing to ascertain locally acquired cases of coccidioidomycosis, Washington, USA. Emerg Infect Dis. 2019;25(3):501-6.

135. Benedict K, et al. Enhanced Surveillance for Coccidioidomycosis, 14 US States, 2016. Emerg Infect Dis. 2018;24(8):1444-52.

136. Blair JE. Coccidioidomycosis in liver transplantation. Liver Transpl. 2006;12(1):31-9.

137. Bowers JR, et al. Direct detection of Coccidioides from Arizona soils using CocciENV, a highly sensitive and specific real-time PCR assay. Med Mycol. 2019;57(2):246-55.

138. Hector RF, Laniado-Laborin R. Coccidioidomycosis-a fungal disease of the Americas. PLoS Med. 2005;2(1):e2.

139. Li Z, Chaturvedi V. The powers and perils of PCR in the search for the natural reservoirs of coccidioides species. Mycopathologia. 2017;182(5-6):435-8.

140. Teixeira MM, Barker BM. Use of population genetics to assess the ecology, evolution, and population structure of coccidioides. Emerg Infect Dis. 2016;22(6):1022-30.

141. Chen S, et al. Coccidioidomycosis: knowledge, attitudes, and practices among healthcare providers-Arizona, 2007. Med Mycol. 2011;49(6):649-56.

142. Cooksey GS, et al. Notes from the field: increase in Coccidioidomycosis-California, 2016. MMWR Morb Mortal Wkly Rep. 2017;66(31):833-4.

143. Wheeler C, Lucas KD, Mohle-Boetani JC. Rates and risk factors for Coccidioidomycosis among prison inmates, California, USA, 2011. Emerg Infect Dis. 2015;21(1):70-5.

144. Centers for Disease Control and Prevention, N.C.f.E.a.Z.I.D.N., Division of Foodborne, Waterborne, and Environmental Diseases (DFWED). Valley Fever (Coccidioidomycosis) Statistics. 2019 [cited 2019; https:// www.cdc.gov/fungal/diseases/coccidioidomycosis/ statistics.html. Accessed 1 Apr 2019

145. Cordeiro REA, et al. Twelve years of coccidioidomycosis in Ceará State, Northeast Brazil: epidemiologic and diagnostic aspects. Diagn Microbiol Infect Dis. 2010;66(1):65-72.

146. Crum N, et al. Coccidioidomycosis outbreak among United States Navy SEALs training in a Coccidioides immitisendemic area-Coalinga, California. J Infect Dis. 2002;186(6):865-8. 
147. Cummings KC, et al. Point-source outbreak of coccidioidomycosis in construction workers. Epidemiol Infect. 2010;138(4):507-11.

148. Freedman M, et al. Coccidioidomycosis outbreaks, United States and Worldwide, 1940-2015. Emerg Infect Dis. 2018;24(3):417-23.

149. Petersen LR, et al. Coccidioidomycosis among workers at an archeological site, northeastern Utah. Emerg Infect Dis. 2004;10(4):637-42.

150. McCotter OZ, et al. Update on the epidemiology of coccidioidomycosis in the United States. Medical Mycology. 2019;57(Suppl 1):S30-40.

151. Lee LA, et al. Increased coccidioidomycosis among inmates at a california prison: initial investigation in 2005 to 2006. J Correct Health Care. 2017;23(3):347-52.

152. Benedict K, McCotter O, Brady S, et al. Surveillance for Coccidioidomycosis-United States, 2011-2017, in MMWR Surveill Summ 2019. 2019.

153. Turabelidze G, et al. Coccidioidomycosis in a state where it is not known to be endemic-Missouri, 2004-2013. MMWR Morb Mortal Wkly Rep. 2015;64(23):636-9.

154. Luna-Isaac JA, et al. Genetic analysis of the endemic fungal pathogens Coccidioides posadasii and Coccidioides immitis in Mexico. Med Mycol. 2014;52(2):156-66.

155. Riera FO, Caeiro JP, Denning DW. Burden of serious fungal infections in Argentina. $\mathrm{J}$ Fungi (Basel). 2018;4(2):51. https://doi.org/10.3390/jof4020051.

156. Gonzalez Ochoa A. Coccidioidomycosis in Mexico. Rev Invest Salud Publica. 1966;26(3):245-62.

157. Mondragón-González R, et al. Detection of Coccidioides immitis infection in Coahuila, Mexico. Rev Argent Microbiol. 2005;37(3):135-8.

158. Cordeiro REA, et al. Serologic detection of coccidioidomycosis antibodies in northeast Brazil. Mycopathologia. 2009;167(4):187-90.

159. Andrade MF, Investigación de la coccidioidomicosis en la capital de Guatemala por medio de la intradermo-reacción a la coccidioidina. 1945, Faculty of Medical Sciences of the University of San Carlos de Guatemala.

160. Castro A, Trejos A. Primer caso centroamericano de coccidioidomicosis. Rev Biol Trop. 1953;1:83-93.

161. Mayorga RP, Espinoza H. Coccidioidomycosis in Mexico and Central America. Mycopathol Mycol Appl. 1970;41(1):13-23.

162. Laniado-Laborín R, et al. Coccidioidomycosis in Latin America. Med Mycol. 2019;57(Suppl 1):S46-55.

163. Negroni R. Historical evolution of some clinical and epidemiological knowledge of coccidioidomycosis in the Americas. Rev Argent Microbiol. 2008;40(4):246-56.

164. Alvarez GG, et al. Blastomycosis in a young African man presenting with a pleural effusion. Can Respir J. 2006;13(8):441-4.

165. Anderson JL, Sloss BL, Meece JK. Clinical and molecular epidemiology of veterinary blastomycosis in Wisconsin. BMC Vet Res. 2013;9:84.

166. Baumgardner DJ, et al. An outbreak of blastomycosis on a United States Indian reservation. Wilderness Environ Med. 2002;13(4):250-2.

167. Crampton TL, et al. Epidemiology and clinical spectrum of blastomycosis diagnosed at Manitoba hospitals. Clin Infect Dis. 2002;34(10):1310-6.
168. McCullough MJ, et al. Molecular epidemiology of Blastomyces dermatitidis. Clin Infect Dis. 2000;30(2):328-35.

169. Smith JA, Gauthier G. New Developments in Blastomycosis. Semin Respir Crit Care Med. 2015;36(5):715-28.

170. Seitz AE, et al. Incidence and trends of blastomycosisassociated hospitalizations in the United States. PLoS ONE. 2014;9(8):e105466.

171. Seitz AE, et al. Spatial epidemiology of blastomycosis hospitalizations: detecting clusters and identifying environmental risk factors. Med Mycol. 2015;53(5):447-54.

172. Baumgardner DJ, et al. Geographic distribution of human blastomycosis cases in Milwaukee, Wisconsin, USA: association with urban watersheds. Mycopathologia. 2006;161(5):275-82.

173. Baumgardner DJ, et al. Geographic information system analysis of blastomycosis in northern Wisconsin, USA: waterways and soil. Med Mycol. 2005;43(2):117-25.

174. Klein BS, et al. Two outbreaks of blastomycosis along rivers in Wisconsin. Isolation of Blastomyces dermatitidis from riverbank soil and evidence of its transmission along waterways. Am Rev Respir Dis. 1987;136(6):1333-8.

175. McTaggart LR, Brown EM, Richardson SE. Phylogeographic analysis of Blastomyces dermatitidis and Blastomyces gilchristii reveals an association with North American freshwater drainage basins. PLoS ONE. 2016;11(7):e0159396.

176. Baumgardner DJ, Burdick JS. An outbreak of human and canine blastomycosis. Rev Infect Dis. 1991;13(5):898-905.

177. Savio J, et al. Blastomycosis in a South Indian patient after visiting an endemic area in USA. Med Mycol. 2006;44(6):523-9.

178. Bonifaz A, Vazquez-Gonzalez D, Perusquia-Ortiz AM. Endemic systemic mycoses: coccidioidomycosis, histoplasmosis, paracoccidioidomycosis and blastomycosis. J Dtsch Dermatol Ges. 2011;9(9): 705-14; quiz 715.

179. Litvinov IV, et al. Endemic human blastomycosis in Quebec, Canada, 1988-2011. Epidemiol Infect. 2013;141(6):1143-7.

180. Manetti AC. Hyperendemic urban blastomycosis. Am J Public Health. 1991;81(5):633-6.

181. Frean JA, et al. Blastomyces dermatitidis infections in the RSA. S Afr Med J. 1989;76(1):13-6.

182. Fragoyannis S, van Wyk G, de Beer M. North American blastomycosis in South Africa: a case report. S Afr Med J. 1977;51(6):169-71.

183. Emmons CW, et al. North American blastomycosis: two autochthonous cases from Africa. Sabouraudia. 1964;3(4):306-11.

184. Emerson PA, Higgins E, Branfoot A. North American blastomycosis in Africans. $\mathrm{Br} \mathrm{J}$ Dis Chest. 1984;78(3):286-91.

185. Ross JJ, Keeling DN. Cutaneous blastomycosis in New Brunswick: case report. CMAJ. 2000;163(10):1303-5.

186. Chakrabarti A, Slavin MA. Endemic fungal infections in the Asia-Pacific region. Med Mycol. 2011;49(4):337-44.

187. Goel A, et al. Extensive extraaxial blastomycosis granuloma at the skull base-case report. Neurol Med Chir (Tokyo). 1996;36(6):393-5.

188. Khan ZU, Randhawa HS, Lulla M. Isolation of Blastomyces dermatitidis from the lungs of a bat, Rhinopoma 
hardwickei hardwickei Gray, Delhi. Sabouraudia. 1982;20(2):137-44.

189. Randhawa HS, et al. Blastomyces dermatitidis in bats: first report of its isolation from the liver of Rhinopoma hardwickei hardwickei Gray. Sabouraudia. 1985;23(1):69-76.

190. Randhawa HS, Khan ZU, Gaur SN. Blastomyces dermatitidis in India: first report of its isolation from clinical material. Sabouraudia. 1983;21(3):215-21.

191. Carman WF, et al. Blastomycosis in Africa. A review of known cases diagnosed between 1951 and 1987. Mycopathologia. 1989;107(1):25-32.

192. Litvinjenko S, Lunny D. Blastomycosis hospitalizations in northwestern Ontario: 2006-2015. Can Commun Dis Rep. 2017;43(10):200-5.

193. De Groote MA, et al. Expanding epidemiology of blastomycosis: clinical features and investigation of 2 cases in Colorado. Clin Infect Dis. 2000;30(3):582-4.

194. MacDonald PD, et al. Human and canine pulmonary blastomycosis, North Carolina, 2001-2002. Emerg Infect Dis. 2006; 12(8):1242-4.

195. Reed KD, et al. Ecologic niche modeling of Blastomyces dermatitidis in Wisconsin. PLoS ONE. 2008;3(4):e2034.

196. Sorensen RH, Casad DE. Use of case survey technique to detect origin of Blastomyces infections. Public Health Rep. 1969;84(6):514-20.

197. Dworkin MS, et al. The epidemiology of blastomycosis in Illinois and factors associated with death. Clin Infect Dis. 2005;41(12):e107-11.

198. Lemos LB, Baliga M, Guo M. Acute respiratory distress syndrome and blastomycosis: presentation of nine cases and review of the literature. Ann Diagn Pathol. 2001;5(1):1-9.

199. Hussein R, et al. Blastomycosis in the mountainous region of northeast Tennessee. Chest. 2009;135(4):1019-23.

200. McDonald R, et al. Notes from the field: blastomycosis cases occurring outside of regions with known endemicity-New York, 2007-2017. MMWR Morb Mortal Wkly Rep. 2018;67(38):1077-8.

201. Frye MD, Seifer FD. An outbreak of blastomycosis in eastern Tennessee. Mycopathologia. 1991;116(1):15-21.

202. Pfaff BL, Agger WA, Volk TJ. Blastomycosis diagnosed in a nonhyperendemic area. WMJ, 2014. 113(1):11-8; quiz 19.

203. Logsdon MT, Jones HE. North American blastomycosis: a review. Cutis. 1979;24(5):524-7, 532-5.

204. Menges RW, Doto IL, Weeks RJ. Epidemiologic studies of blastomycosis in Arkansas. Arch Environ Health. 1969;18(6):956-71.

205. Lowry PW, Kelso KY, McFarland LM. Blastomycosis in Washington Parish, Louisiana, 1976-1985. Am J Epidemiol. 1989;130(1):151-9.

206. Proctor ME, et al. Cluster of pulmonary blastomycosis in a rural community: evidence for multiple high-risk environmental foci following a sustained period of diminished precipitation. Mycopathologia. 2002;153(3):113-20.

207. Vasquez JE, et al. Blastomycosis in northeast Tennessee. Chest. 1998;114(2):436-43.

208. Azar MM, et al. Blastomycosis in Indiana: clinical and epidemiologic patterns of disease gleaned from a multicenter retrospective study. Chest. 2015;148(5):1276-84.
209. Pfister AK, Hamaty D. A survey of North American blastomycosis in West Virginia. W V Med J. 1966;62(12):434-5.

210. Permpalung $\mathrm{N}$, et al. Pulmonary blastomycosis: a new endemic area in New York state. Mycoses. 2013;56(5):592-5.

211. Sen BL, Ahmad I, Easom HF. Pulmonary blastomycosis in eastern North Carolina. Report of fifteen cases. N C Med J, 1967;28(7): 264-8.

212. Kralt D, et al. Clinical characteristics and outcomes in patients with pulmonary blastomycosis. Mycopathologia. 2009;167(3):115-24.

213. Kane J, et al. Blastomycosis: a new endemic focus in Canada. Can Med Assoc J. 1983;129(7):728-31.

214. Lester RS, et al. Novel cases of blastomycosis acquired in Toronto. Ontario. Cmaj. 2000;163(10):1309-12.

215. Lohrenz S, et al. Blastomycosis in Southern Saskatchewan 2000-2015: unique presentations and disease characteristics. Med Mycol. 2018;56(7):787-95.

216. Chander B, et al. Cerebral blastomycosis: a case report. Indian J Pathol Microbiol. 2007;50(4):821-4.

217. Koen AF, Blumberg LH. North American blastomycosis in South Africa simulating tuberculosis. Clin Radiol. 1999;54(4):260-2.

218. Baily GG, et al. Blastomycosis in Africa: clinical features, diagnosis, and treatment. Rev Infect Dis. 1991;13(5):1005-8.

219. Harket A, et al. Cutaneous blastomycosis revealing intravascular B-cell lymphoma: a case in Morocco. Med Trop (Mars). 2007;67(3):278-80.

220. Ferchichi L, et al. Three cases of cutaneous blastomycosis. Med Mal Infect. 2006;36(5):285-7.

221. Jordaan HF. Blastomycosis in Namibia-report of a case successfully treated with itraconazole. Clin Exp Dermatol. 1989;14(5):347-51.

222. Ibrahim TM, Edinol ST. Pleural effusion from blastomycetes in an adult Nigerian: a case report. Niger Postgrad Med J. 2001;8(3):148-9.

223. Raftopoulos $\mathrm{C}$, et al. Intracerebellar blastomycosis abscess in an African man. Clin Neurol Neurosurg. 1986;88(3):209-12.

224. Gatti F, Renoirte R, Vandepitte J. 1st Case of North American Blastomycosis Observed in the Congo (Leopoldville). Ann Soc Belges Med Trop Parasitol Mycol. 1964;44:1057-66.

225. Campos-Magalhaes M, Drouhet E, Destombes P, [1st case of blastomycosis due to Blastomyces dermatitidis observed in Mozambique. Cure by amphotericin B]. Bull Soc Pathol Exot Filiales. 1968;61(2):210-8.

226. Lythcott GI, Edgcomb JJ. The Occurrence of South American Blastomycosis in Accra. Ghana. Lancet. 1964;1(7339):916-7.

227. Bhagwandeen SB. North American blastomycosis in Zambia. Am J Trop Med Hyg. 1974;23(2):231-4.

228. Liautaud B, et al. [Blastomyces dermatitidis blastomycosis in Africa. First Algerian case]. Bull Soc Pathol Exot Filiales. 1976;69(2):125-34.

229. Schwartz IS, et al. Blastomyces helicus, a new dimorphic fungus causing fatal pulmonary and systemic disease in humans and animals in western Canada and the United States. Clin Infect Dis. 2019;68(2):188-95. 
230. Wagner G, et al. Chronic Paracoccidioidomycosis with adrenal involvement mimicking tuberculosis-a case report from Austria. Med Mycol Case Rep. 2016;14:12-6.

231. Yoshimura Y, et al. A case of paracoccidioidomycosis with severe adrenal insufficiency. Kansenshogaku Zasshi. 2012;86(3):291-4.

232. Vieira Gde D, et al. Paracoccidioidomycosis in a western Brazilian Amazon State: clinical-epidemiologic profile and spatial distribution of the disease. Rev Soc Bras Med Trop. 2014;47(1):63-8.

233. Vicente CR, Falqueto A. Differentiation of mucosal lesions in mucocutaneous leishmaniasis and paracoccidioidomycosis. PLoS ONE. 2018;13(11):e0208208.

234. Tristao FS, et al. 5-Lipoxygenase activity increases susceptibility to experimental Paracoccidioides brasiliensis infection. Infect Immun. 2013;81(4):1256-66.

235. Sylvestre TF, et al. Prevalence and serological diagnosis of relapse in paracoccidioidomycosis patients. PLoS Negl Trop Dis. 2014;8(5):e2834.

236. Shikanai-Yasuda MA, et al. [Brazilian guidelines for the clinical management of paracoccidioidomycosis]. Epidemiol Serv Saude. 2018;27(spe): e0500001.

237. Roberto TN, et al. Identifying Paracoccidioides phylogenetic species by PCR-RFLP of the alpha-tubulin gene. Med Mycol. 2016;54(3):240-7.

238. Martinez R. New trends in paracoccidioidomycosis epidemiology. J Fungi (Basel). 2017;3(1):1. https://doi.org/ 10.3390/jof3010001.

239. Martinez R. Epidemiology of paracoccidioidomycosis. Rev Inst Med Trop Sao Paulo. 2015;57(Suppl 19):11-20.

240. Mangiaterra ML, et al. Paracoccidioides brasiliensis infection in a subtropical region with important environmental changes. Bull Soc Pathol Exot. 1999;92(3):173-6.

241. Bernardes Filho F, et al. Acute paracoccidioidomycosis with duodenal and cutaneous involvement and obstructive jaundice. Med Mycol Case Rep. 2018;20:21-5.

242. Albano AP, et al. Seroepidemiology of Paracoccidioides brasiliensis infection in horses from Rio Grande do Sul. Brazil. Braz J Microbiol. 2015;46(2):513-7.

243. Albano AP, et al. Wild animals as sentinels of Paracoccidioides brasiliensis in the state of Rio Grande do Sul. Brazil. Mycopathologia. 2014;177(3-4):207-15.

244. Almeida OP, Jacks J Jr, Scully C. Paracoccidioidomycosis of the mouth: an emerging deep mycosis. Crit Rev Oral Biol Med. 2003;14(5):377-83.

245. Vidal MS, et al. Serological diagnosis of paracoccidioidomycosis: high rate of inter-laboratorial variability among medical mycology reference centers. PLoS Negl Trop Dis. 2014;8(9):e3174.

246. Trindade $\mathrm{AH}$, et al. Oral paracoccidioidomycosis: retrospective analysis of 55 Brazilian patients. Mycoses. 2017;60(8):521-5.

247. Simoes LB, Marques SA, Bagagli E. Distribution of paracoccidioidomycosis: determination of ecologic correlates through spatial analyses. Med Mycol. 2004;42(6):517-23.

248. Martinez R. Paracoccidioidomycosis: the dimension of the problem of a neglected disease. Rev Soc Bras Med Trop. 2010;43(4):480.
249. do Valle ACF, et al. Paracoccidioidomycosis after highway construction, Rio de Janeiro. Brazil. Emerg Infect Dis. 2017;23(11):1917-9.

250. Morejon KM, Machado AA, Martinez R. Paracoccidioidomycosis in patients infected with and not infected with human immunodeficiency virus: a case-control study. Am J Trop Med Hyg. 2009;80(3):359-66.

251. Griffiths J, Lopes Colombo A, Denning DW. The case for paracoccidioidomycosis to be accepted as a neglected tropical (fungal) disease. PLoS Negl Trop Dis. 2019;13(5): e0007195.

252. Magalhaes EM, et al. Prevalence of paracoccidioidomycosis infection by intradermal reaction in rural areas in Alfenas, Minas Gerais, Brazil. Rev Inst Med Trop Sao Paulo. 2014;56(4):281-5.

253. Pecanha PM, et al. Paracoccidioidomycosis: epidemiological and clinical aspects in 546 cases studied in the state of Espirito Santo. Brazil. Am J Trop Med Hyg. 2017;97(3):836-44.

254. Bellissimo-Rodrigues F, Machado AA, Martinez R. Paracoccidioidomycosis epidemiological features of a 1000-cases series from a hyperendemic area on the southeast of Brazil. Am J Trop Med Hyg. 2011;85(3):546-50.

255. Marques-da-Silva SH, et al. Occurrence of Paracoccidioides lutzii in the Amazon region: description of two cases. Am J Trop Med Hyg. 2012;87(4):710-4.

256. Fujio J, Nishimura K, Miyaji M. Epidemiological survey of the imported mycoses in Japan. Nihon Ishinkin Gakkai Zasshi. 1999;40(2):103-9.

257. Blotta $\mathrm{MH}$, et al. Endemic regions of paracoccidioidomycosis in Brazil: a clinical and epidemiologic study of 584 cases in the southeast region. Am J Trop Med Hyg. 1999;61(3):390-4.

258. Lopez-Martinez R, et al. Paracoccidioidomycosis in Mexico: clinical and epidemiological data from 93 new cases (1972-2012). Mycoses. 2014;57(9):525-30.

259. de Almeida SM, et al. Geographical evaluation of Neuroparacoccidioidomycosis and Paracoccidioidomycosis in Southern Brazil. Mycoses. 2018;61(8):587-93.

260. Kamei K, et al. The trend of imported mycoses in Japan. J Infect Chemother. 2003;9(1):16-20.

261. Jacyk WK, Lawande RV, Tulpule SS. Deep mycoses in West Africa: a report of 13 cases and review of the Nigerian literature. J Natl Med Assoc. 1981;73(3):251-6.

262. Buitrago MJ, et al. Utility of real-time PCR for the detection of Paracoccidioides brasiliensis DNA in the diagnosis of imported paracoccidioidomycosis. Med Mycol. 2009;47(8):879-82.

263. Brauninger W, Hastra K, Rubin R. Paracoccidioidomycosis, an imported tropical disease. Hautarzt. 1985;36(7):408-11.

264. Marques SA. Paracoccidioidomycosis: epidemiological, clinical, diagnostic and treatment up-dating. An Bras Dermatol. 2013;88(5):700-11.

265. Yoshimura Y, et al. Penicillium marneffei infection with beta-D-glucan elevation: a case report and literature review. Intern Med. 2016;55(17):2503-6.

266. Wong SS, Siau H, Yuen KY. Penicilliosis marneffei-West meets East. J Med Microbiol. 1999;48(11):973-5. 
267. Wang $\mathrm{P}$, et al. Acute disseminated Talaromyces marneffei in an immunocompetent patient. Mycopathologia. 2017;182(7-8):751-4.

268. Vanittanakom N, et al. Penicillium marneffei infection and recent advances in the epidemiology and molecular biology aspects. Clin Microbiol Rev. 2006;19(1):95-110.

269. Srinoulprasert Y, et al. Engagement of Penicillium marneffei conidia with multiple pattern recognition receptors on human monocytes. Microbiol Immunol. 2009;53(3):162-72.

270. Sirisanthana T, Supparatpinyo K. Epidemiology and management of penicilliosis in human immunodeficiency virus-infected patients. Int J Infect Dis. 1998;3(1):48-53.

271. Singh PN, et al. Indigenous disseminated Penicillium marneffei infection in the state of Manipur, India: report of four autochthonous cases. J Clin Microbiol. 1999;37(8):2699-702.

272. Qiu Y, et al. Differences in clinical characteristics and prognosis of Penicilliosis among HIV-negative patients with or without underlying disease in Southern China: a retrospective study. BMC Infect Dis. 2015;15:525.

273. Patassi AA, et al. First observation in a non-endemic country (Togo) of Penicillium marneffei infection in a human immunodeficiency virus-infected patient: a case report. BMC Res Notes. 2013;6:506.

274. Pracharktam R, Sriurairatna S, Jayanetra P. Morphological variation in pathogenic strains of Penicillium marneffei. J Med Assoc Thai. 1992;75(Suppl 1):172-9.

275. DiSalvo AF, Fickling AM, Ajello L. Infection caused by Penicillium marneffei: description of first natural infection in man. Am J Clin Pathol. 1973;60(2):259-63.

276. $\mathrm{Hu} \mathrm{Y}$, et al. Penicillium marneffei infection: an emerging disease in mainland China. Mycopathologia. 2013;175(1-2):57-67.

277. Deng Z, et al. Infections caused by Penicillium marneffei in China and Southeast Asia: review of eighteen published cases and report of four more Chinese cases. Rev Infect Dis. 1988;10(3):640-52.

278. Saikia L, Nath R, Mahanta J. Penicillium marneffei infection in Assam. Indian J Dermatol Venereol Leprol. 2010;76(1):75-6.

279. Saikia L, et al. Atypical cutaneous lesions of Penicillium marneffei infection as a manifestation of the immune reconstitution inflammatory syndrome after highly active antiretroviral therapy. Indian J Dermatol Venereol Leprol. 2010;76(1):45-8.

280. Ranjana KH, et al. Disseminated Penicillium marneffei infection among HIV-infected patients in Manipur state. India. J Infect. 2002;45(4):268-71.

281. Lee SS, Lo YC, Wong KH. The first one hundred AIDS cases in Hong Kong. Chin Med J (Engl). 1996;109(1):70-6.

282. Pei SN, Lee CH, Liu JW. Hemophagocytic syndrome in a patient with acquired immunodeficiency syndrome and acute disseminated penicilliosis. Am J Trop Med Hyg. 2008;78(1):11-3.

283. Jung JY, et al. Disseminated penicilliosis in a Korean human immunodeficiency virus infected patient from Laos. J Korean Med Sci. 2012;27(6):697-700.
284. Saadiah S, Jeffrey AH, Mohamed AL. Penicillium marneffei infection in a non aids patient: first case report from Malaysia. Med J Malaysia. 1999;54(2):264-6.

285. Mohsin J, et al. Imported talaromycosis in oman in advanced HIV: a diagnostic challenge outside the endemic areas. Mycopathologia. 2017;182(7-8):739-45.

286. Sood N, Gugnani HC. Disseminated Penicillium marneffei infection in a Myanmar refugee from Mizoram state. Indian J Pathol Microbiol. 2010;53(2):361-3.

287. Hien TV, et al. First cases of disseminated penicilliosis marneffei infection among patients with acquired immunodeficiency syndrome in Vietnam. Clin Infect Dis. 2001;32(4):e78-80.

288. Browne SK, et al. Adult-onset immunodeficiency in Thailand and Taiwan. N Engl J Med. 2012;367(8):725-34.

289. Kenyon C, et al. A dimorphic fungus causing disseminated infection in South Africa. $N$ Engl $J$ Med. 2013;369(15):1416-24.

290. Jiang Y, et al. Phylogeny, ecology and taxonomy of systemic pathogens and their relatives in Ajellomycetaceae (Onygenales): blastomyces, emergomyces, emmonsia, emmonsiellopsis. Fungal Diversity. 2018;90(1):245-91.

291. Marin-Felix Y, et al. Emmonsiellopsis, a new genus related to the thermally dimorphic fungi of the family Ajellomycetaceae. Mycoses. 2015;58(8):451-60.

292. Schwartz IS, et al. AIDS-related endemic mycoses in western cape, South Africa, and clinical mimics: a crosssectional study of adults with advanced HIV and recentonset, Widespread Skin Lesions. Open Forum Infect Dis. 2017;4(4): ofx186.

293. Schwartz IS, et al. Emergomyces africanus in soil, South Africa. Emerg Infect Dis. 2018;24(2):377-80.

294. Pelegrin I, et al. Disseminated adiaspiromycosis: case report of a liver transplant patient with human immunodeficiency infection, and literature review. Transpl Infect Dis. 2011;13(5):507-14.

295. Feng P, et al. Disseminated infection caused by Emmonsia pasteuriana in a renal transplant recipient. J Dermatol. 2015;42(12):1179-82.

296. Gast KB, et al. Two cases of Emergomyces pasteurianus infection in immunocompromised patients in the Netherlands. Med Mycol Case Rep. 2019;24:5-8.

297. Gori S, et al. Cutaneous disseminated mycosis in a patient with AIDS due to a new dimorphic fungus. J Mycol Med. 1998;8:57-63.

298. Rooms I, et al. Disseminated emergomycosis in a person with HIV infection. Uganda Emerg Infect Dis. 2019;25(9):1750-1.

299. Schwartz IS, Maphanga TG, Govender NP. Emergomyces: a new genus of dimorphic fungal pathogens causing disseminated disease among immunocompromised persons globally. Curr Fungal Infect Rep. 2018;12(1):44-50.

300. Friedman DZP, Schwartz IS. Emerging fungal infections: new patients, new patterns, and new pathogens. J Fungi (Basel). 2019;5(3):67. https://doi.org/10.3390/ jof5030067.

301. Wang P, et al. A novel dimorphic pathogen, Emergomyces orientalis (Onygenales), agent of disseminated infection. Mycoses. 2017;60(5):310-9. 
302. Wellinghausen $\mathrm{N}$, et al. Chronic granulomatous lung infection caused by the dimorphic fungus Emmonsia sp. Int J Med Microbiol. 2003;293(6):441-5.

303. Ajello L. The medical mycological iceberg. HSMHA Health Rep. 1971;86(5):437-48.

304. Imperato PJ, Diakite S. Histoplasmin sensitivity in Mali. Results of a recent skin-test survey with the intradermal jet injector. Am J Trop Med Hyg. 1969;18(2):264-7.

305. Gugnani HC, Egere JU, Larsh H. Skin sensitivity to capsulatum and duboisii histoplasmins in Nigeria. J Trop Med Hyg. 1991;94(1):24-6.

306. Wen FQ, et al. Prevalence of histoplasmin sensitivity in healthy adults and tuberculosis patients in southwest China. J Med Vet Mycol. 1996;34(3):171-4.

307. Edwards PQ, et al. Histoplasmin testing in Africa and Southern Asia. Am J Trop Med Hyg. 1956;5(2):224-34.

308. Azhar Tanjung M. Prevalensi histoplasmosis pada mahasiswa kedokteran Universitas Islam Sumatera Utara dan hubungan hewan peliharaan dengan tes histoplasmin. Berkala Ilmu Kedokteran. 1997;29:139-44.

309. Schuman ND, Mackey DM, Safrit HF. Histoplasmin Sensitivity Investigation in the Third Division of Sarawak, Borneo. Am Rev Respir Dis. 1963;88:261-3.

310. Ponnampalam JT. A review of histoplasmosis in Malaya. Med J Malaya. 1968;23(4):295-8.

311. Edwards PQ. Histoplasmin Sensitivity of Young Men in Alaska, Hawaii, the Philippines and Puerto Rico. Bull World Health Organ. 1964;30:587-94.

312. Jayanetra $P$, et al. The magnitude of the public health problem posed by the mycoses. J Infect Dis Antimicrob Agents. 1987;4(4):175-84.

313. Prijyanonda B, et al. Histoplasmin sensitivity in medical students and student nurses at Siriraj Hospital. J Med Assoc Thai. 1967;50:67-77.

314. Hay RJ, et al. Histoplasmosis in the eastern Caribbean: a preliminary survey of the incidence of the infection. J Trop Med Hyg. 1981;84(1):9-12.

315. Mangiaterra $\mathbf{M}$, et al. Histoplasmin and paracoccidioidin skin reactivity in infantile population of northern Argentina (1). Rev Inst Med Trop Sao Paulo. 1996;38(5):349-53.

316. Quinones F, et al. Histoplasmosis in Belize, Central America. Am J Trop Med Hyg. 1978;27(3):558-61.

317. Coimbra Junior CE, et al. Paracoccidioidin and histoplasmin sensitivity in Tupi-Monde Amerindian populations from Brazilian Amazonia. Ann Trop Med Parasitol. 1994;88(2):197-207.

318. Tesh RB, Marques RJ. Histoplasmin sensitivity in Brazil. Report of recent skin test survey in Recife (Pernambuco) and Belem (Para) and review of other surveys in various areas of the country. Am J Trop Med Hyg. 1966;15(3):359-63.

319. Rodrigues MT, de Resende MA. Epidemiologic skin test survey of sensitivity to paracoccidioidin, histoplasmin and sporotrichin among gold mine workers of Morro Velho Mining, Brazil. Mycopathologia. 1996;135(2):89-98.

320. Restrepo A, et al. Distribution of paracoccidioidin sensitivity in Colombia. Am J Trop Med Hyg. 1968;17(1):25-37.
321. Taylor RL, Dobrovolny CG. The distribution of histoplasmin sensitivity in Guatemala. Am J Trop Med Hyg. 1960;9:518-22.

322. Taylor ML, et al. Immunologic, genetic and social human risk factors associated to histoplasmosis: studies in the State of Guerrero, Mexico. Mycopathologia. 1997;138(3):137-42.

323. Cermeno JR, et al. Epidemiological survey of histoplasmine and paracoccidioidine skin reactivity in an agricultural area in Bolivar state, Venezuela. Eur J Epidemiol. 2004;19(2):189-93.

324. Bagagli E, et al. Isolation of Paracoccidioides brasiliensis from armadillos (Dasypus noveminctus) captured in an endemic area of paracoccidioidomycosis. Am J Trop Med Hyg. 1998;58(4):505-12.

325. Barrozo LV, et al. Climate and acute/subacute paracoccidioidomycosis in a hyper-endemic area in Brazil. Int $\mathbf{J}$ Epidemiol. 2009;38(6):1642-9.

326. Bellissimo-Rodrigues F, et al. Endemic paracoccidioidomycosis: relationship between clinical presentation and patients' demographic features. Med Mycol. 2013;51(3):313-8.

327. Goncalves AJ, et al. Paracoccidioidomycosis in children in the state of Rio de Janeiro (Brazil). Geographic distribution and the study of a "reservarea". Rev Inst Med Trop Sao Paulo. 1998;40(1):11-3.

328. de Macedo PM, et al. Acute juvenile Paracoccidioidomycosis: a 9-year cohort study in the endemic area of Rio de Janeiro, Brazil. PLoS Negl Trop Dis. 2017;11(3):e0005500.

329. Vergara ML, Martinez R. Role of the armadillo Dasypus novemcinctus in the epidemiology of paracoccidioidomycosis. Mycopathologia. 1998;144(3):131-3.

330. Silveira LH, et al. Occurrence of antibodies to Paracoccidioides brasiliensis in dairy cattle from Mato Grosso do Sul, Brazil. Mycopathologia. 2008;165(6):367-71.

331. Fornajeiro N, et al. Paracoccidioidomycosis epidemiological survey using gp43, in two cities of northwestern region of Parana, Brazil. Rev Soc Bras Med Trop. 2005;38(2):191-3.

332. Loth EA, et al. Occurrence of 102 cases of paracoccidioidomycosis in 18 months in the Itaipu Lake region, Western Parana. Rev Soc Bras Med Trop. 2011;44(5):636-7.

333. Verli FD, et al. Clinical-epidemiologic profile of paracoccidioidomycosis at the Stomatology Department of Sao Lucas Hospital, Pontificia Universidade Catolica of Rio Grande do Sul. Rev Soc Bras Med Trop. 2005;38(3):234-7.

334. de Souza SP, Jorge VM, Xavier MO. Paracoccidioidomycosis in southern Rio Grande do Sul: a retrospective study of histopathologically diagnosed cases. Braz J Microbiol. 2014;45(1):243-7.

335. Tichellio AG, Mangiaterra M, Giusiano G. Paracoccidioidomycosis in Formosa province (Argentina). Rev Argent Microbiol. 2008;40(1):24-9.

336. Cermeno J, et al. Epidemiological study of paracoccidioidomycosis and histoplasmosis in a suburb of San Felix city, Bolivar state, Venezuela. Invest Clin. 2009;50(2):213-20. 
337. Talhari S, et al. Deep mycoses in Amazon region. Int $\mathbf{J}$ Dermatol. 1988;27(7):481-4.

338. Matos WB, et al. Paracoccidioidomycosis in the state of Maranhao, Brazil: geographical and clinical aspects. Rev Soc Bras Med Trop. 2012;45(3):385-9.

339. Deng ZL, Connor DH. Progressive disseminated penicilliosis caused by Penicillium marneffei. Report of eight cases and differentiation of the causative organism from Histoplasma capsulatum. Am J Clin Pathol. 1985;84(3):323-7.

340. Cao C, et al. The effects of temperature, $\mathrm{pH}$, and salinity on the growth and dimorphism of Penicillium marneffei. Med Mycol. 2007;45(5):401-7.

341. Li H, et al. Disseminated Penicillium Marneffei infection with verrucoid lesions in an AIDS patient in Beijing, a non-endemic region. Eur J Dermatol. 2010;20(3):378-80.

342. Fan $\mathrm{H}$, et al. Pediatric hyperimmunoglobulin E syndrome: a case series of 4 children in China. Medicine (Baltimore). 2018;97(14):e0215.

343. Nong S, Liang J. Bone marrow Penicillium marneffei infection in acquired immunodeficiency syndrome patients: report of 35 cases. Trop Biomed. 2013;30(1):89-91.

344. Hsueh PR, et al. Molecular evidence for strain dissemination of Penicillium marneffei: an emerging pathogen in Taiwan. J Infect Dis. 2000;181(5):1706-12.

345. Luh KT. Penicillium marneffei fungemia in an AIDS patient: the first case report in Taiwan. Changgeng Yi Xue Za Zhi. 1998;21(3):362.

346. Wang YG, et al. Study on the clinical features and prognosis of penicilliosis marneffei without human immunodeficiency virus infection. Mycopathologia. 2018;183(3):551-8.

347. Chan JF, et al. Talaromyces (Penicillium) marneffei infection in non-HIV-infected patients. Emerg Microbes Infect. 2016;5:e19.

348. Wong SCY, et al. Fatal Talaromyces marneffei infection in a patient with autoimmune hepatitis. Mycopathologia. 2018;183(3):615-8.

349. Lee PP, et al. Penicillium marneffei infection and impaired IFN-gamma immunity in humans with autosomal-dominant gain-of-phosphorylation STAT1 mutations. J Allergy Clin Immunol. 2014;133(3): 894-6 e5.

350. Chan JF, et al. Reactive and infective dermatoses associated with adult-onset immunodeficiency due to anti-interferon-gamma autoantibody: sweet's syndrome and beyond. Dermatology. 2013;226(2):157-66.
351. Hung HG, Lok KH. Intestinal Penicillium marneffei: an unusual cause of chronic diarrhea in an AIDS patient. J Dig Dis. 2010;11(3):189-91.

352. Ma BH, et al. Recurrent hemoptysis with Penicillium marneffei and Stenotrophomonas maltophilia in Job's syndrome. Can Respir J. 2009;16(4):e50-2.

353. $\mathrm{Wu} \mathrm{TC}$, et al. Clinical presentations and outcomes of Penicillium marneffei infections: a series from 1994 to 2004. Hong Kong Med J. 2008;14(2):103-9.

354. Chariyalertsak $\mathrm{S}$, et al. Case-control study of risk factors for Penicillium marneffei infection in human immunodeficiency virus-infected patients in northern Thailand. Clin Infect Dis. 1997;24(6):1080-6.

355. Antinori S, et al. Disseminated Penicillium marneffei infection in an HIV-positive Italian patient and a review of cases reported outside endemic regions. J Travel Med. 2006;13(3):181-8.

356. Faksri K, et al. Epidemiology and identification of potential fungal pathogens causing invasive fungal infections in a tertiary care hospital in northeast Thailand. Med Mycol. 2014;52(8):810-8.

357. Norredam M, et al. Talaromyces marneffei fungaemia in a patient from Thailand with newly diagnosed HIV. Ugeskr Laeger. 2017;179(8):2-3.

358. Le T, et al. Epidemiology, seasonality, and predictors of outcome of AIDS-associated Penicillium marneffei infection in Ho Chi Minh City, Viet Nam. Clin Infect Dis. 2011;52(7):945-52.

359. Le T, et al. AIDS-associated Penicillium marneffei infection of the central nervous system. Clin Infect Dis. 2010;51(12):1458-62.

360. Bulterys PL, et al. Environmental predictors and incubation period of AIDS-associated penicillium marneffei infection in Ho Chi Minh City, Vietnam. Clin Infect Dis. 2013;56(9):1273-9.

361. Maniar JK, et al. Penicillium marneffei infection: an AIDS-defining illness. Indian J Dermatol Venereol Leprol. 2005;71(3):202-4.

362. Clyti E, et al. Penicilliosis in Laos. Presse Med. 2006;35(3 Pt 1):427-9.

Publisher's Note Springer Nature remains neutral with regard to jurisdictional claims in published maps and institutional affiliations. 